\title{
A escola como instrumento do dever constitucional de enfrentamento da homofobia: potencialidade e tensões
}

\author{
Daniel Carvalho Cardinali \\ Mestre em Direito Público pela Universidade do Estado do Rio de Janeiro (UERJ). \\ Bacharel em Direito pela UERJ. E-mail: danielcardinali@hotmail.com
}

\section{Resumo}

$\mathrm{O}$ artigo tem por objetivo analisar o papel que a escola pode desempenhar no combate à homofobia. A primeira parte irá examinar a homofobia, entendida como uma injustiça no campo cultural, decorrente de um modelo de heterossexualidade compulsória e dominação masculina, a demandar de políticas de reconhecimento para o seu enfrentamento. Posteriormente, será analisado de que maneira estas políticas de reconhecimento são previstas na Constituição de 1988, para concluir que esta prevê a obrigação do Estado em adotá-las. Partindo desta premissa, a terceira parte examinará o potencial privilegiado que a escola assume neste cenário, abordando o papel central que ela desempenha na produção da homofobia e a função que pode vir a desempenhar para a sua desconstrução. Finalmente, serão analisadas as disputas e tensões que envolvem o tema, principalmente em razão do discurso conservador e religioso e da formulação da categoria de "ideologia de gênero".

\section{Palavras-chave}

Educação; Homofobia; “Ideologia de gênero”; Igualdade; Reconhecimento.

\section{School as constitutional duty instrument in the struggle against homophobia: possibilities and tensions}

\begin{abstract}
This article aims to analyze the role the school can have in the struggle against homophobia. The first part will examine homophobia, understood as an injustice in the cultural field that derives from a model of compulsory heterosexuality and male domination, which calls for politics of recognition. Then it will be analyzed in what fashion
\end{abstract}


these politics of recognition are laid down on the Constitution of 1988, in order to conclude that it establish an obligation of the State to adopt them. On the basis of this premise, the third part examines the privileged potential that school assumes in this scenario, addresing the central role it plays in the production of homophobia and role it may play in its unmaking. Finally, the debates and tensions regarding the subject will be analyzed, specially those that arose of conservative and religious discourse and the formulation of the category of "gender ideology".

\section{Keywords}

Education; Homophobia; "Gender ideology"; Equality; Recognition.

\section{Sumário}

Introdução. 1. A homofobia como problema de reconhecimento. 2. O dever constitucional de enfrentamento à homofobia. 3. A escola como espaço privilegiado de enfrentamento da homofobia. 4. Disputas e tensões. Conclusão. Bibliografia.

\section{Introdução ${ }^{1}$}

A Constituição de 1988 é marcada pela centralidade conferida à dignidade da pessoa humana e aos direitos fundamentais, simbolicamente positivados logo em seu início, bem como pelo "compromisso profundo e visceral com a igualdade" 2 na busca pela construção de um Brasil mais justo e mais tolerante com a pluralidade. A partir deste novo paradigma axiológico, ganha relevância a visão do direito como um instrumento de emancipação social. Assim, a nova ordem constitucional tem servido de fundamento para uma série de discursos e movimentos que visam desconstruir padrões culturais atávicos sobre os quais grassa toda sorte de preconceitos e discriminações. Neste quadro, a Carta de 1988 é considerada como o "marco fundamental a partir do qual a sexualidade e a reprodução se instituem como campo legítimo de exercício de direitos no Brasil” ${ }^{3}$, servindo dessa forma de alicerce normativo das políticas públicas desenvolvidas em favor da diversidade sexual e no combate à homofobia.

Em que pese esse cenário, a "orientação sexual” não está expressamente prevista dentre os motivos de discriminação vedados no art. 3ำ, IV da Constituição, a sua inclusão neste rol foi a principal bandeira do movimento homossexual durante a Assembleia Constituinte. A proposta, entretanto, não logrou êxito ${ }^{4}$, e os debates em torno da medida

\footnotetext{
${ }^{1} \mathrm{O}$ autor agradece as críticas e comentários dos pareceristas da revista que ajudaram no aperfeiçoamento do texto.

2 SARMENTO, Daniel. "A Igualdade Étnico-Racial no Direito Constitucional Brasileiro: Discriminação 'De Facto', Teoria do Impacto Desproporcional e Ação Afirmativa". In: SARMENTO, Daniel. Livres e Iguais: Estudos de Direito Constitucional. Rio de Janeiro: Lumen Juris, 2006, p. 141.

${ }^{3}$ CARRARA, Sérgio. "Políticas e direitos sexuais no Brasil contemporâneo". In: Bagoas, no 05, 2010, p. 134.

${ }^{4}$ Apesar de não ter sido incluída na Constituição Federal, a vedação da discriminação por orientação sexual foi incluída nas Constituições Estaduais de Mato Grosso e Sergipe, e nas Leis Orgânicas de vários municípios.
} 
revelaram uma resistência enorme dos parlamentares em torno do tema, que entendiam que a previsão iria estimular a libidinagem, a imoralidade e a devassidão, e que serviria apenas para incentivar os "maus costumes", ridicularizar as instituições oficiais e propagar a epidemia de AIDS $^{5}$.

Por outro lado, parece induvidoso que a discriminação em razão da orientação sexual é vedada pela ordem constitucional de 1988, mesmo que de maneira implícita. A própria abertura do supracitado art. 3o, IV, a "quaisquer outras formas de discriminação", bem como o espírito francamente emancipatório da nova Constituição legitimam tal entendimento ${ }^{6}$. Para Roger Raupp Rios, a discriminação em razão da identidade sexual estaria abarcada pela discriminação em razão do sexo, explicitamente vedada pelo texto constitucional, em função de o sujeito homossexual ser discriminado com base no sexo daquele a quem dirige seu envolvimento afetivo-sexual ${ }^{7}$.

Assim, partindo desta premissa, cabe questionar que medidas a ordem constitucional de 1988 demanda do Estado em face daquilo que é comumente denominado de homofobia. O enfrentamento desta realidade pode ser concretizado por uma gama complexa de ações de distintas ordens, que vão desde a repressão e punição dos comportamentos discriminatórios, até medidas positivas que visam intervir na realidade em favor da diversidade sexual. O presente artigo tem por foco este segundo tipo de medida, buscando a análise de como a adoção de políticas públicas de combate à homofobia no campo da educação e da escola detém um potencial privilegiado de transformação social, baseando-se para tanto na teoria de Nancy Fraser a respeito do reconhecimento.

A primeira parte do artigo irá realizar um exame do problema a ser enfrentado, buscando entender a homofobia como uma injustiça no campo do reconhecimento que decorre de padrões culturais assimétricos e estigmatizantes, e que requer para o seu enfrentamento políticas de reconhecimento, a partir das chaves teóricas desenvolvidas

${ }^{5}$ A proposta recebeu inclusive a alcunha pouco elogiosa de "emenda da desorientação sexual" (TREVISAN, João Silvério. Devassos no Paraíso: a homossexualidade no Brasil, da colônia à atualidade. 8a Ed. Rio de Janeiro: Record, 2011, p. 158). Sobre as propostas e os debates na constituinte a respeito do tema, vide: MARMELSTEIN, George. "Jurisprudência arco-íris: comentários à decisão do Supremo Tribunal Federal acerca das uniões homoafetivas". In: Revista Brasileira de Direito Constitucional-RBDC, n. 17, 2011, pp. 233-235.

${ }^{6}$ SARMENTO, Daniel. "Casamento e União Estável entre Pessoas do Mesmo Sexo: perspectivas constitucionais". In: SARMENTO, Daniel; IKAWA, Daniela; PIOVESAN, Flávia (coords.). Igualdade, Diferença e Direitos Humanos. Rio de Janeito: Lumen Juris, 2010, p. 636.

7 RIOS, Roger Raupp. "Direito da antidiscriminação, sexo, sexualidade e gênero: a compreensão da proibição constitucional de discriminação por motivo de sexo". In: SARMENTO, Daniel; IKAWA, Daniela; PIOVESAN, Flávia (coords.). Igualdade, Diferença e Direitos Humanos. Rio de Janeiro: Lumen Juris, 2010, pp. 714-717. 
por Nancy Fraser. Neste sentido, serão sumarizadas as suas bases culturais, como a eleição da heterossexualidade como única orientação sexual legítima/possível e a dominação masculina caracterizada pela estratificação dos papéis de gênero e a superioridade do masculino em relação ao feminino.

A segunda parte irá abordar o dever constitucional de adoção de políticas de reconhecimento para o enfrentamento da homofobia, analisando os seus fundamentos normativos na ordem constitucional brasileira e, principalmente, a necessidade de adoção de medidas positivas de intervenção na realidade, que se consubstanciam em políticas públicas de valorização das diferenças e do pluralismo.

Dentre estas diversas medidas, a intervenção no campo da educação tem um potencial privilegiado. Assim, a terceira seção analisará, em primeiro lugar, de que maneira a escola atua como uma instância normalizadora e disciplinadora de produção e reprodução de uma cultura homofóbica, para, em um segundo momento, explorar as possibilidades de a escola assumir um papel de desconstrução de uma cultura de intolerância e preconceito.

Finalmente, a quarta e última parte abordará as disputas e tensões a que se submete a adoção das políticas na esfera educacional analisadas na seção anterior, decorrentes principalmente da ação por parte de grupos religiosos e conservadores, que pretendem que as escolas atuem no reforço da noção de um modelo monolítico de família e vivência sexual e se opõem ao que chamam de "ideologia de gênero".

\section{A homofobia como problema de reconhecimento}

A discriminação e o preconceito sofridos por pessoas que possuem uma orientação sexual ou prática afetivo-sexual não heterossexual, seja está real ou presumida/suposta ${ }^{8}$, são tradicionalmente denominados de homofobia. Embora amplamente adotado no discurso da academia e da militância, tendo posteriormente se popularizado e se tornado corrente, o termo é objeto de críticas e propostas alternativas. Alguns autores advogam que o uso do sufixo -fobia poderia passar a ideia de que se trata de uma psicopatologia de ordem individual, apagando os componentes social, cultural, jurídico e institucional da discriminação. Outros termos sugeridos dão maior destaque a estes aspectos, como por

\footnotetext{
8 Um caso representativo dessa situação envolveu um pai e um filho que, ao se abraçarem, foram confundidos com um casal gay e agredidos em São João da Boa Vista, interior de São Paulo, em 2011. 
exemplo, heterossexismo e heteronormatividade ${ }^{9}$.

Tendo em vista a sua ampla disseminação, a expressão será adotada neste artigo, devendo se ressalvar desde logo que se adere à crítica formulada, no sentido de que a discriminação sofrida por pessoas não-heterossexuais decorre não somente de atitudes individuais, mas principalmente dos padrões sociais, institucionais e culturais que as produzem ${ }^{10}$. Borrillo define homofobia como:

\begin{abstract}
A hostilidade geral, psicológica e social contra aquelas e aqueles que, supostamente, sentem desejo ou têm práticas sexuais com indivíduos de seu próprio sexo. Forma específica de sexismo, a homofobia rejeita, igualmente, todos aqueles que não se conformam com o papel predeterminado para $o$ seu sexo biológico. Construção ideológica que consiste na promoção constante de uma forma de sexualidade (hétero) em detrimento de outra (homo), a homofobia organiza uma hierarquização das sexualidades e, dessa forma, extrai consequências políticas ${ }^{11}$.
\end{abstract}

Pode-se perceber, portanto, que a homofobia é fruto de um sistema hierarquizante que valoriza de forma assimétrica os sujeitos em razão de sua orientação sexual ${ }^{12}$. Erigida à padrão único, a heterossexualidade se torna compulsória, e toda forma de vivência e experiência que se afaste desse modelo é desvalorizada. Mais do que isso, a heterossexualidade é encarada como modelo natural, correto e sadio, enquanto práticas desviantes são tachadas de antinaturais, patológicas ou pecaminosas.

A supracitada definição de Borrillo explicita a inter-relação que existe entre a homofobia e a discriminação sofrida pelas mulheres, na medida em que ambas estão relacionadas ao patriarcalismo e à dominação masculina, que impõe papéis sociais distintos, rígidos e desiguais, a homens e mulheres, justificados com base na sua naturalidade e inevitabilidade ("diferencialismo sexual") e na superioridade do masculino

${ }^{9}$ RIOS, Roger Raupp. "O conceito de homofobia na perspectiva dos direitos humanos e no contexto dos estudos sobre preconceito e discriminação". In: RIOS, Roger Raupp. (org.). Em Defesa dos Direitos Sexuais. Porto Alegre: Livraria do Advogado Ed., 2007, p. 120; JUNQUEIRA, Rogério Diniz. "Homofobia: limites e possibilidades de um conceito em meio a disputas". Revista Bagoas, V.1, n.1, jul./dez. 2007, p. 10.

${ }_{10}$ Por outro lado, mesmo a reação individual de asco e repúdio viscerais, costumeiramente relacionada à noção de "fobia", diante da homossexualidade e da afetividade entre pessoas do mesmo sexo "pode ser interpretada como objeção política à visibilidade dessas minorias, associada a disposições conservadoras tocantes à moral sexual". In: NATIVIDADE, Marcelo; OLIVEIRA, Leandro de. As novas guerras sexuais: diferença, poder religioso e identidades LGBT no Brasil. Rio de Janeiro: Garamond, 2013, p. 78.

${ }^{11}$ BORRILLO, Daniel. Homofobia: história e crítica de um preconceito. Belo Horizonte: Autêntica, 2010. p. 34.

${ }^{12}$ Assim, "na ideologia e no sistema heterossexisas, mais do que uma questão de preferência ou orientação sexuais, o binômio heterossexualidade/homossexualidade é critério distintivo para o reconhecimento da dignidade dos sujeitos e para a distribuição dos benefícios sociais políticos e econômicos". In: RIOS, R. R. "O conceito de homofobia na perspectiva dos direitos humanos e no contexto dos estudos sobre preconceito e discriminação". Op. Cit, p. 121.

Revista Publicum

Rio de Janeiro, v. 3, n. 1, 2017, p. 157-189.

http://www.e-publicacoes.uerj.br/index.php/publicum

DOI: 10.12957/publicum.2017.27322 
em relação ao feminino ${ }^{13}$.

Neste sentido, a homossexualidade entra em choque com este modelo hegemônico na medida em que desafia as performances de gênero em diversos níveis, como, por exemplo, nos papéis sexuais, uma vez que a homossexualidade é capaz de fazer com que homens assumam uma postura passiva, que é destinada às mulheres ${ }^{14}$; e que mulheres assumam uma postura ativa, reservada aos homens ${ }^{15}$. Assim, se a construção tradicional da masculinidade e da feminilidade se dá em grande medida pela separação estanque entre os dois universos, opostos e especulares, a experiência homossexual produz um embaralhamento dessas fronteiras ${ }^{16}$, que a homofobia visa a restabelecer e reforçar a todo momento ${ }^{17}$. Com efeito, a homofobia atua como um dispositivo de defesa do modelo hegemônico que pretende uma linearidade entre o sexo, gênero e desejo/orientação sexual, estabelecendo a legitimidade somente das vivências de gênero que estejam "em acordo" com o sexo "natural" do sujeito e das orientações sexuais que estejam voltadas para o gênero/sexo oposto ${ }^{18}$.

${ }^{13}$ Ibidem, p. 122. Sobre o tema, Eribon argumenta que a dominação masculina deve ser entendida de forma ampla, "como a dominação do 'princípio masculino' sobre o 'princípio feminino' e, portanto, do homem heterossexual (isto é, o homem!) sobre o homem homossexual (que não é considerado um homem), na medida em que a homossexualidade é classificada no inconsciente de nossas sociedades do lado do 'feminino'”'. In: ERIBON, Didier. Reflexões sobre a questão gay. Rio de Janeiro: Companhia de Freud, 2008, p. 101.

${ }^{14}$ Não por acaso, o estigma decorrente a prática homossexual masculina é modulado pelo papel sexual desempenhado: aquele que exerce o papel ativo e "masculino" muitas vezes sequer é considerado como homossexual ou como "não-homem", enquanto aquele que se sujeita ao papel passivo e "feminino" emascula-se em definitivo e deixa de ser considerado como "homem de verdade" (Ibidem, pp. 115-119).

${ }^{15}$ Neste sentido, Miskolci diferencia homofobia e heteronormatividade para argumentar que esta seria a ordem sexual e de papeis de gênero hegemônica, e que poderia inclusive ser reproduzida por casais do mesmo sexo na medida em que estes emulem comportamentos tradicionais e atuem no apagamento de vivências desviantes de gênero. Assim, as experiências homossexuais estariam submetidas a níveis distintos de estigmatização social na medida do afastamento em relação ao modelo hegemônico de vivência de gênero e de família preconizado pela ordem heteronormativa. In: MISKOLCl, Richard. Teoria Queer: um aprendizado pelas diferenças. 2a Ed. Belo Horizonte: Autêntica, 2015, p. 15.

${ }^{16}$ Não por acaso a homossexualidade foi percebida pelo discurso médico no fim do século XIX como uma questão de "inversão de gênero", e o homem homossexual como alguém que renunciava à sua masculinidade, assim como a lésbica à sua feminilidade. In: ERIBON, Didier. Reflexões sobre a questão gay. Op. Cit., pp. 101-102.

17 WELZER-LANG, Daniel. "A Construção do Masculino: dominação das mulheres e homofobia". Estudos Feministas. Florianópolis, v. 9, n. 2, 2001, p. 465.

${ }^{18}$ Sobre esta linearidade, Zambrano e Heilborn argumentam que: "o senso comum considera que uma pessoa, ao ser classificada como homem ou mulher (sexo biológico), terá naturalmente o sentimento e o comportamento esperados de cada uma dessas possibilidades (identidade/papel de gênero masculino ou feminino), e que seu desejo sexual será dirigido para pessoas do sexo e/ou gênero diferente do seu (orientação heterossexual). Esses três elementos - sexo, gênero e orientação - são pensados em nossa cultura como sempre combinados do mesmo modo, isto é, cria-se um padrão hegemônico de ser homem masculino ou mulher feminina heterossexual".ZAMBRANO, Elizabeth; HEILBORN, Maria Luiza. "Identidade de gênero". In: LIMA, 
Segundo Judith Butler, essa coerência e continuidade entre sexo, gênero, prática sexual e desejo produz gêneros "inteligíveis", culturalmente aceitáveis, que, a partir de uma relação de causalidade e inter-relação entre estes elementos (e.g. se macho, logo masculino) torna os sujeitos que não se amoldam a este enquadramento como ininteligíveis ${ }^{19}$. Assim, para a autora:

\begin{abstract}
A heterossexualização do desejo requer e institui a produção de oposições discriminadas e assimétricas entre 'feminino' e 'masculino', em que estes são compreendidos como atributos expressivos de 'macho' e de 'fêmea'. A matriz cultural por meio da qual a identidade de gênero se torna inteligivel exige que certos tipos de 'identidade' não possam 'existir' - isto é, aqueles em que o gênero não decorre do sexo e aqueles que as práticas do desejo não 'decorrem' nem do 'sexo' nem do 'gênero'. [...] Ora, do ponto de vista desse campo, certos tipos de 'identidade de gênero' parecem ser meras falhas do desenvolvimento ou impossibilidades lógicas, precisamente por não se conformarem às normas de inteligibilidade cultural20.
\end{abstract}

Berenice Bento destaca essa relação de complementariedade e retroalimentação entre a heterossexualidade e o binarismo de gênero, uma vez que o modelo dicotômico e complementar de gêneros-sexos justificaria a heterossexualidade como padrão natural e inquestionável, ao mesmo tempo em que o disciplinamento das performances de gênero de acordo com este modelo único servira ao controle das sexualidades desviantes ${ }^{21}$. De acordo com Borrillo, a divisão binária de gêneros e o desejo heterossexual são dispositivos de reprodução da ordem social, não somente da reprodução biológica da espécie humana. Daí a visão da homofobia como uma "guardiã das fronteiras tanto sexuais (hétero/homo) como de gênero (masculino/feminino)"22.

Assim, o combate à discriminação sofrida por mulheres e por homossexuais envolveria um mesmo "inimigo comum", o que historicamente aproximou as demandas do movimento feminista e do movimento LGBT. Ambos os movimentos pretendem a

Antonio Carlos de Souza (coord.). Antropologia \& Direito: temas antropológicos para estudos jurídicos. Rio de Janeiro/Brasília: Contra Capa, 2012, p. 415.

19 BUTLER, Judith. Problemas de Gênero: feminismo e subversão da identidade. 8a Ed. Rio de Janeiro: Civilização Brasileira, 2015, p. 43.

${ }^{20}$ Ibidem, p. 44

${ }^{21}$ BENTO, Berenice. "Na escola se aprende que a diferença faz a diferença". In: Estudos Feministas, 19(2), 2011, p. 553. Em sentido semelhante, Butler defende que "a instituição de uma heterossexualidade compulsória e naturalizada exige e regula o gênero como uma relação binária em que o termo masculino diferencia-se do termo feminino, realizando-se essa diferenciação por meio das práticas do desejo heterossexual. $O$ ato de diferenciar os dois momentos oposicionais da estrutura binária resulta numa consolidação de cada um de seus termos, da coerência interna respectiva do sexo, do gênero e do desejo". In: Butler, J. Problemas de Gênero. Op. Cit. p. 53

22 BORRILLO, D. Homofobia. Op. Cit., p. 16. 
"politização do cotidiano" e a "publicização do privado"23, e colocam em debate a separação rígida de papéis de gênero masculinos e femininos, seja no âmbito da família, seja em outros espaços sociais, bem como uma cultura profundamente machista e patriarcal que posiciona o homem e a masculinidade/virilidade como superiores à mulher e à feminilidade. Segundo Castells, o movimento LGBT põe em risco o patriarcalismo ao afrontar a suas premissas de "heterossexualidade compulsória" e de "repressão sexual", sobre as quais se estabeleceu historicamente uma rígida e hierárquica divisão de papéis sexuais e de gênero ${ }^{24}$.

Estas estruturas de repressão sexual e heterossexualidade compulsória a que se refere o autor sofrem os influxos no Brasil - e na América Latina de forma geral - da formação cristã da nossa matriz cultural e da influência persistente da Igreja Católica e da cosmovisão cristão na política. Neste sentido, o modelo de família hegemônico, não apenas heterossexual ("Deus fez macho e fêmea”), mas também matrimonial, indissolúvel e profundamente patriarcal, corresponde ao modelo único preconizado pelo catolicismo, e que deve ser defendido em face das influências disruptivas do feminismo e das lutas de minorias sexuais.

Diante de todo o exposto, é fácil perceber que a homofobia representa uma desigualdade ou injustiça de ordem cultural. Segundo Nancy Fraser, as injustiças podem ter causas econômicas, requerendo remédios baseados em políticas de redistribuição; ou causas culturais, que demandam para o seu enfrentamento políticas de reconhecimento ${ }^{25}$.Fraser entende que, ao contrário do que ocorre com a raça e o

\footnotetext{
${ }^{23}$ Assim, "as teóricas feministas há muito argumentam que 'o pessoal é político', querendo com isso dizer que o aparentemente 'natural' domínio privado da intimidade (a família e a sexualidade) é legalmente construído, culturalmente definido, e constitui lócus de relações de poder. Na maioria delas, a ênfase foi posta na desconstrução crítica da retórica da privacidade como parte de um discurso de dominação legitimador da opressão das mulheres".COHEN, Jean L. "Repensando a privacidade: autonomia, identidade e controvérsia sobre o aborto". In: Revista Brasileira de Ciência Política, no 7. Brasília, janeiro/abril de 2012, p. 169.

${ }^{24}$ CASTELLS, Manuel. O poder da identidade. 8a Ed. São Paulo: Paz e Terra, 1999. pp. 238 e 256.

25 "Cada dimensão está associada a uma dimensão analiticamente distinta de injustiça. Para a dimensão de reconhecimento [...] a injustiça associada é o não-reconhecimento, no qual padrões arraigados de valor cultural negam a alguns atores a importância necessária para participar integralmente da vida social. Para a dimensão distributiva, por sua vez, a injustiça correspondente à má distribuição, na qual as estruturas econômicas, tais como regimes de propriedade e mercados de trabalho, privam alguns atores dos recursos necessários. Cada dimensão, por fim, corresponde a uma forma analiticamente distinta de subordinação. A dimensão do reconhecimento corresponde, como já vimos, à subordinação de status enraizada em padrões institucionalizados de valor cultural. A dimensão distributiva, por sua vez, corresponde à subordinação econômica, enraizada em características estruturais do sistema econômico". FRASER, Nancy. "Repensando a questão do reconhecimento: superar a substituição e a reificação na política cultural”. In: BALDI, César Augusto. (org.). Direitos Humanos na Sociedade Cosmopolita. Rio de Janeiro: Renovar, 2004, pp. 616-617. Por outro lado, deve ser destacado que a autora entende ser possível a existência de outras formas de injustiça, i.e, outras formas de ordenação social produtoras de outras formas de subordinação,
} 
gênero ${ }^{26}$, a injustiça em razão da orientação sexual seria arquetípica de um problema de reconhecimento, decorrente de "padrões institucionalizados de valor cultural que constroem a heterossexualidade como natural e normativa e a homossexualidade como perversa e desprezível"27.

Segundo a autora, as injustiças de reconhecimento são tradicionalmente concebidas como "distorções de identidade", com base na noção hegeliana de que a identidade se constrói intersubjetivamente ${ }^{28}$ A autora, entretanto, busca desenvolver um modelo alternativo, que enxerga o não-reconhecimento como um problema de "status social" ${ }^{29}$. De acordo com este modelo, deve-se analisar os padrões institucionalizados de valor cultural pelos seus efeitos sobre a posição relativa dos atores sociais; isto é, quando estes padrões encararem os atores como iguais, conferindo-lhes o mesmo valor, poderia se falar em igualdade e reconhecimento recíproco, ao passo que padrões diferentes, que encaram os atores como inferiores ou superiores, produziriam exclusão e desigualdade, por meio de uma subordinação de status e não-reconhecimento ${ }^{30}$.

Uma noção central no pensamento de Fraser é a de paridade de participação, que

destacando que talvez a dimensão política poderia ser considerada uma candidata a este tertium genus. FRASER, Nancy. "Social Justice in the Age of Identity Politics: Redistribution, Recognition, and Participation". In: FRASER, Nancy; HONNETH, Axel. Redistribution or Recognition?: a politicalphilosophical exchange. Londres: Verso, 2003. p. 68.

${ }^{26}$ Apesar da elegância e didatismo dessa bipartição teórica, a autora advoga que as políticas de reconhecimento e redistribuição não são necessariamente excludentes, e que as injustiças concretas podem assumir ambas as faces simultaneamente, que ela chama de "coletividades bivalentes", como seria o caso da injustiça em razão do gênero ou da raça. Assim, embora algumas injustiças se aproximem mais de um ou outro extremo, as injustiças concretas poderiam ser arranjadas ao longo de um gradiente entre os dois polos da redistribuição e do reconhecimento, requerendo, para seu enfrentamento, remédios de ambos os tipos. FRASER, Nancy. "Redistribuição, Reconhecimento e Participação: por uma Concepção Integrada de Justiça". In: SARMENTO, Daniel; IKAWA, Daniela; PIOVESAN, Flávia. (coords.). Igualdade, Diferença e Direitos Humanos. Rio de Janeiro: Lumen Juris, 2010, pp. pp. 171-178. A autora defende, portanto, que a noção de "dualismo perspectivo" entende que reconhecimento e redistribuição podem ser entendidos como "analiticamente distintas", não ocupando concretamente esferas sociais separadas, na medida em que "se interpenetram para produzir padrões complexos de subordinação" ("distribution and recognition do not occupy separate spheres. Rather, they interpenetrate, to produce complex patterns of subordination"; FRASER, Nancy "Distorted Beyond All Recognition: A rejoinder to Axel Honneth". FRASER, Nancy; HONNETH, Axel. Redistribution or Recognition?: a political-philosophical exchange. Londres: Verso, 2004, p. 217).

27 "Institutionalized patterns of cultural value construct heterosexuality as natural and normative, homosexuality as perverse and despised". (FRASER, N. "Social Justice in the Age of Identity Politics. p. 18). Apesar disso, a autora reconhece que problemas de redistribuição podem derivar destes padrões culturais assimétricos. Assim, por exemplo, uma pessoa pode ser demitida ou ser impedida de gozar de um benefício previdenciário em razão de sua orientação sexual. Neste sentido, injustiças por reconhecimento podem, concretamente, necessitar de alguma política de redistribuição, de tal forma que, do ponto de vista prático todos os tipos de subordinação podem ser entendidos como bidimensionais (Ibidem, pp. 24-25).

28 FRASER, N. "Repensando a questão do reconhecimento". Op. Cit, pp. 604 et seq.

29 Ibidem, pp. 610 et seq.

${ }^{30}$ FRASER, N. "Social Justice in the Age of Identity Politics". Op. Cit.. pp. 29-30. 
exige todos os membros da sociedade possam interagir entre si como parceiros livres e iguais, requerendo para isso a distribuição de bens materiais suficientes (condição objetiva) e padrões culturais de igual respeito (condição intersubjetiva) ${ }^{31}$. É justamente com base nessa ideia normativa que a autora vai justificar o dever de adoção de políticas de redistribuição e reconhecimento ${ }^{32}$. Neste sentido, o objetivo das políticas de reconhecimento seria a paridade de participação na sua condição intersubjetiva, isto é, a construção de um mundo tolerante e respeitoso com a diferença, no qual a assimilação a padrões culturais hegemônicos não fosse um preço necessário a ser pago pelas minorias para o gozo de seus direitos ${ }^{33}$.

\section{O dever constitucional de enfrentamento à homofobia}

O dever de adoção de políticas de reconhecimento para o combate às desigualdades decorrentes de padrões culturais que produzem status de subordinação - como a homofobia - encontra guarida na ordem constitucional de 1988. Discute-se academicamente se o reconhecimento no campo constitucional deriva do princípio da dignidade da pessoa humana ${ }^{34}$, do princípio da igualdade ${ }^{35}$ ou do direito de liberdade ${ }^{36}$. Independentemente do seu fundamento normativo, fato é que a dimensão do reconhecimento dos sujeitos detém hierarquia constitucional enquanto direito fundamental, devendo o poder público observá-la. Mais do que isso, impõe aos poderes públicos a adoção de políticas de reconhecimento com vistas à transformação da realidade, buscando a superação de padrões culturais assimétricos e estigmatizantes ${ }^{37}$.

Trabalhando a partir do princípio da igualdade, Piovesan destaca que a ordem constitucional previu a igualdade não apenas em uma dimensão negativa, de proibição e repressão da discriminação; mas também em uma dimensão positiva que visa promover a inclusão de grupos estigmatizados. Segundo a autora, "a proibição da exclusão, em si

\footnotetext{
${ }^{31}$ Ibidem. pp. 36-37.

32 FRASER, N. “Distorted Beyond All Recognition. Op. Cit, p. 217, p. 218.

33 Ibidem. p. 7.

${ }^{34}$ SARMENTO, Daniel. Dignidade da Pessoa Humana: conteúdo, trajetórias e metodologia. Belo Horizonte: Fórum, 2016, pp. 255-257.

35 BARROSO, Luís Roberto; OSÓRIO, Aline Rezende Peres. "Sabe com quem está falando?": Algumas notas sobre o princípio da igualdade no Brasil contemporâneo. pp. 8 et seq. Disponível em: <http://www.luisrobertobarroso.com.br/wp-

content/themes/LRB/pdf/SELA_Yale_palestra_igualdade_versao_fina.pdf $>$. Acesso em: 21.04.2017.

${ }^{36}$ LOPES, José Reinaldo de Lima. "O direito ao reconhecimento para gays e lésbicas". In: Sur Revista Internacional de Direitos Humanos, ano 2, Número 2, 2005, p. 86.

37 Ibidem, p. 82.
} 
mesma, não resulta automaticamente na inclusão" ${ }^{38}$. Assim, a ordem constitucional não apenas veda a discriminação homofóbica, seja por parte do poder público, seja por parte dos agentes privados, mas exorta a adoção de medidas enérgicas e ativas para a transformação social e a superação de um quadro fático de intolerância e discriminação.

Por outro lado, Sarmento chega a mesma conclusão encarando o reconhecimento como corolário da dignidade da pessoa humana:

É possivel falar em um direito fundamental ao reconhecimento, que é um direito ao igual respeito da identidade pessoal. Trata-se de um direito que tem uma faceta negativa como outra positiva. Em sua faceta negativa, ele veda as práticas que desrespeitam as pessoas em sua identidade, estigmatizando-as. Na dimensão positivam ele impõe ao Estado a adoção de medidas voltadas ao combate dessas práticas e à superação dos estigmas existentes ${ }^{39}$.

Com efeito, a Constituição de 1988 foi muito além de uma visão formal ou absenteísta com relação ao papel do Estado diante das desigualdades e discriminações concretamente existentes. $\mathrm{O}$ art. 3o define programaticamente como objetivos fundamentais da República Federativa do Brasil, dentre outros, "erradicar a pobreza e a marginalização e reduzir as desigualdades sociais e regionais" (inciso III) e "promover o bem de todos, sem preconceitos de origem, raça, sexo, cor, idade e quaisquer outras formas de discriminação" (inciso IV), enquanto o preâmbulo preconiza a construção de "uma sociedade fraterna, pluralista e sem preconceitos". Assim, a igualdade deve ser entendida não apenas como um princípio fundamental, mas também como um objetivo constitucional a ser perseguido.

Neste sentido, o constituinte exorta o Estado a agir positivamente para a desconstrução de padrões culturais produtores de assimetrias e hierarquias. O uso constante de verbos de ação para tratar do tema reforça a ideia de que o constituinte não se resignou diante da falta de igualdade da sociedade brasileira, mas antes que este credita ao Estado um papel transformador e emancipatório que deve ser vigorosamente exercido $^{40}$. Nesse cenário, o Estado brasileiro é visto como "um instrumento para a consecução de fins da comunidade política", dentre os quais tem destaque "a promoção da igualdade, efetiva e concreta" ${ }^{41}$.

38 PIOVESAN, Flávia. Temas de Direitos Humanos. 3a Ed. São Paulo: Saraiva, 2009, p. 189

39 SARMENTO, Daniel. Dignidade da Pessoa Humana. Op. Cit, pp. 256-257.

${ }^{40}$ SARMENTO, Daniel. "A Igualdade Étnico-Racial no Direito Constitucional Brasileiro". Op. Cit., p. 142.

${ }^{41}$ CASTRO, Carlos Roberto Siqueira. "A nova dimensão da igualdade". In: CASTRO, Carlos Roberto Siqueira. Constituição Aberta e os Direitos Fundamentais: Ensaios sobre o constitucionalismo pósmoderno e comunitário. 2a Ed. Rio de Janeiro: Forense, 2010, p. 361.

Revista Publicum

Rio de Janeiro, v. 3, n. 1, 2017, p. 157-189.

http://www.e-publicacoes.uerj.br/index.php/publicum

DOI: 10.12957/publicum.2017.27322 
A valorização explícita das minorias étnicas (índios e negros) ${ }^{42}$ e de gênero (mulheres) ${ }^{43}$ no sistema constitucional advém da percepção de que grupos historicamente estigmatizados muitas vezes não são adequadamente contemplados por enunciações genéricas, bem como da sua importância na formação de uma sociedade plural e tolerante. Assim, a superação de padrões culturais produtores de injustiças de reconhecimento se relaciona ao chamado direito à diferença, que importa na valorização simbólica das diferenças, o que impõe ao Estado uma postura mais atuante, ativa e propositiva com vistas à proteção das manifestações e dos grupos minoritários em face da homogeneização, assimilação, do preconceito e dos padrões culturais excludentes Neste sentido, o direito à diferença pode ser entendido nesta dupla função por meio da já clássica construção de Boaventura Souza Santos:

Temos o direito a ser iguais quando a nossa diferença nos inferioriza; e temos o direito a ser diferentes quando à nossa igualdade nos descaracteriza. Daí a necessidade de uma igualdade que reconheça as diferenças e de uma diferença que não produza, alimente ou reproduza as desigualdades ${ }^{44}$.

A observância do direito à diferença passa muitas vezes pela própria ressignificação da diferença, isto é, daqueles atributos estigmatizantes e socialmente desprestigiados. Assim, se as desigualdades no campo do reconhecimento derivam de representações sociais hierarquizantes e homogeneizantes de raça/cor, gênero, sexualidades, credos etc., o seu enfrentamento requer a desconstrução destas representações negativas por meio da valorização e celebração do pluralismo, da diversidade e das diferenças/particularidades culturais de cada grupo social ${ }^{45}$. 0 direito à diferença e o reconhecimento encontram-se, assim, umbilicalmente ligados à valorização do pluralismo e da diversidade como forma de fomentar uma ética da tolerância e da alteridade. Vianna

\footnotetext{
42 Assim, por exemplo, criminalização do racismo (art. 5o, XLII); a possibilidade do ensino em línguas indígenas (art. 210, §2); a valorização e proteção das manifestações culturais indígenas e afrobrasileiras (art. 215); a proteção dos costumes e comunidades indígenas, especialmente no direito à terra (arts. 231 e 232); a valorização da contribuição das diferentes culturas e etnias no ensino da história do Brasil (art. 242, §1으); o reconhecimento da propriedade das comunidades quilombolas (art. 68 do ADCT).

${ }^{43}$ Assim, por exemplo, proteção específica no mercado de trabalho (art. 70, XX), idade e tempo de contribuição menores para a aposentadoria (arts. 40, III e 201, §7으), garantia de igualdade no âmbito da família (art. 226, §3으 e §5으).

${ }^{43}$ SANTOS, Boaventura de Sousa. Reconhecer para Libertar: Os caminhos do cosmopolitismo multicultural. Rio de Janeiro: Civilização Brasileira, 2003, p. 56.

${ }^{44}$ SANTOS, Boaventura de Sousa. Reconhecer para Libertar: Os caminhos do cosmopolitismo multicultural. Rio de Janeiro: Civilização Brasileira, 2003, p. 56.

45 FRY, Peter. "Diferenças, desigualdade e discriminação". In. LIMA, Antonio Carlos de Souza (coord.). Antropologia \& Direito: temas antropológicos para estudos jurídicos. Rio de Janeiro/Brasília: Contra Capa, 2012, pp. 230-232.
} 
afirma, neste diapasão, que:

Falar de "direito à diferença" implica, em primeiro lugar, reconhecer a possibilidade de heterogeneidade cultural e social como algo legítimo em universos políticos mais amplos, dotados de uma suposta "unidade" [...]. Mais do que apreender a diferença como condição inerente aos grupos sociais, isso equivale a defendê-la como algo relevante na constituição da especificidade de indivíduos e coletividades que não desejam negá-la para serem reconhecidos como participantes legítimos de unidades abrangentes ${ }^{46}$.

Diante do exposto, é possível concluir que, se a discriminação em razão da orientação sexual é rechaçada pela ordem constitucional, a qual impõe aos poderes públicos, além de um mero dever negativo de vedação da exclusão, um dever positivo de promoção da inclusão, o Estado tem o dever de adotar políticas públicas de reconhecimento com o fim de desconstruir os padrões culturais produtores da homofobia analisados na seção anterior. Assim, se a homofobia decorre de um sistema que hierarquiza as distintas orientações sexuais, erigindo a heterossexualidade como modelo único, o direito à diferença pugna pela adoção de políticas de reconhecimento que valorizem outras formas possíveis de vivenciar a sexualidade, defendendo a sua legitimidade. Igualmente, se a homofobia deriva de um modelo de vivências de gênero exclusivo, faz-se necessária a adoção de medidas que confrontem este modelo.

Por outro lado, a noção de políticas de reconhecimento deve ser entendida de forma abrangente, agrupando uma infinidade de medidas possíveis para o enfrentamento das situações de injustiça cultural. Assim, por exemplo, a garantia formal de direitos iguais às uniões entre pessoas do mesmo sexo em relação às famílias formadas por homens e mulheres é provavelmente a mais saliente política de reconhecimento no campo dos direitos homossexuais, e uma medida que possui considerável potencial de enfrentamento da homofobia, questionando as preconcepções de gênero e modelo familiar que the alimentam e permitindo que as pessoas abandonem seus preconceitos e preconcepções no tocante à homossexualidade ao conviverem com famílias formadas por dois homens ou duas mulheres. A partir desta noção, a próxima seção analisará um dos possíveis campos específicos de atuação destas políticas.

\section{A escola como espaço privilegiado de enfrentamento da}

46 VIANNA, Adriana de Resende Barreto. "Direito à Diferença: introdução". In: LIMA, Antonio Carlos de Souza (coord.). Antropologia \& Direito: temas antropológicos para estudos jurídicos. Rio de Janeiro/Brasília: Contra Capa, 2012, p 205.

Revista Publicum

Rio de Janeiro, v. 3, n. 1, 2017, p. 157-189.

http://www.e-publicacoes.uerj.br/index.php/publicum

DOI: 10.12957/publicum.2017.27322 


\section{homofobia}

Como vimos, as políticas de reconhecimento podem ser entendidas como medidas que pretendem questionar uma dada realidade sociocultural e intervir para a sua transformação, com o objetivo de torná-la mais pluralista, tolerante e emancipatória. Ademais, a adoção de tais medidas pelo poder público é um dever constitucional. Dentro deste quadro, a escola e a educação assumem um papel central por dois motivos interrelacionados. Em primeiro lugar pelo protagonismo que ocupam na produção e no reforço de padrões culturais assimétricos e, neste sentido, da própria realidade sobre a qual se pretende intervir ${ }^{47}$. Assim, conforme será abordado, as escolas são espaços de normalização e produção das bases culturais da homofobia. Por outro lado, a educação também detém destacada potencialidade de intervenção nesta realidade que ajuda a construir, podendo ser um espaço não de reforço, mas de superação da homofobia ${ }^{48}$. Tal situação é retratada por Debora Diniz e Tatiana Lionço:

Nas escolas, além da transmissão formal de conhecimento, constituem-se espaços públicos para a promoção da cidadania e para o exercício dos direitos humanos. Neste sentido, a escola é um espaço que permite a representação da realidade social em sua diversidade, podendo ser uma ferramenta política emancipatória. Todavia, conforme as práticas vigentes e os conteúdos veiculados, este mesmo espaço pode ser marcado pela discriminação, numa dinâmica que valoriza as diferenças de modo a produzir desigualdades e prejuizos para as partes desqualificadas ${ }^{49}$.

Analisando de que maneira as escolas atuam no reforço da homofobia, deve ser destacado que a escola é um espaço de pronunciada construção de uma noção generificada de mundo, atuando na reprodução das noções ínsitas à dominação masculina e à estratificação dos papeis de gênero, em relação tanto às "diferenças naturais" entre os gêneros, quanto à superioridade masculina. Assim, por exemplo, é comum o recurso - e, dessa forma, o reforço e a naturalização - da divisão de gêneros no ambiente escolar em

\footnotetext{
47 Segundo Junqueira, "o campo da educação se constituiu historicamente como um espaço disciplinador, normalizador e reprodutor de desigualdades" (JUNQUEIRA, Rogério Diniz. "Políticas de educação para a diversidade sexual: escola como lugar de direitos. In: LIONÇO, Tatiana; DINIZ, Debora. (Orgs.). Homofobia \& Educação: um desafio ao silêncio. Brasília: LetrasLivres, EdUnB, 2009, p. 162). Em sentido semelhante, Nancy Fraser aponta que padrões de valor impeditivos da paridade de participação continuam regulando as interações nas mais importantes instituições sociais, como a educação (FRASER, N. "Social Justice in the Age of Identity Politics". Op. Cit.. p. 57).

4848 SOUZA, Elizeu Clementino de. "Direitos humanos e diversidade sexual na escola: homofobia, trabalho docente e cotidiano escolar". Conjectura: filosofia e educação; v. 20, no especial, 2015, p. 200.

49 DINIZ, Debora; LIONÇO, Tatiana. "Educação, direitos sexuais, laicidade e diversidade sexual”. In: RIOS, Roger Raupp; GOLIN, Célio; LEIVAS, Paulo Gilberto Cogo. Homossexualidade e Direitos Sexuais: reflexões a partir da decisão do STF. Porto Alegre: Sulina, 2011, p. 125.
}

Revista Publicum

Rio de Janeiro, v. 3, n. 1, 2017, p. 157-189.

http://www.e-publicacoes.uerj.br/index.php/publicum

DOI: 10.12957/publicum.2017.27322 
vários níveis: do ponto de vista organizacional (por exemplo, "fila de meninos, fila de meninas"); das atividades (por exemplo, na divisão nos esportes praticados nas aulas de educação física); dos uniformes etc ${ }^{50}$. Não por acaso os próprios estabelecimentos foram historicamente segregados com base na divisão binária de gênero, com instituições exclusivamente masculinas ou femininas ${ }^{51}$. Mais do que isso, o reforço dos papéis de gênero no ambiente escolar ocorre de forma ainda mais sutil - e nem por isso menos poderosa - a partir, por exemplo, das expectativas de atividade, agitação e dinamismo ligada à virilidade dos meninos em oposição a um "bom comportamento" ou "capricho" das meninas (e.g. "letra de menina"), que coloca como desviantes de gênero as meninas mais enérgicas ou os meninos mais introvertidos ${ }^{52}$.

Assim, Miskolci argumenta que a educação e a escola detêm um papel importante na produção, reprodução e reforço das normas de gênero "dirigidas para a construção de homens e mulheres ideais, leia-se: pessoas 'normais', 'corretas', como nossa sociedade nos faz crer que devemos ser"53. Igualmente, Junqueira entende a escola como um "espaço obstinado na produção, reprodução e atualização dos parâmetros de heteronormatividade" e como "uma instituição fortemente empenhada na reafirmação e na garantia do êxito dos processos de heterossexualização compulsória e de incorporação das normas de gênero" 54 . A garantia desta função normalizadora decorreria não apenas da organização rigidamente generificada, mas também por meio dos rígidos controles, vigilância e correção disciplinares dos corpos e sujeitos em formação.

Não por acaso a experiência escolar costuma ser especialmente traumática para os sujeitos cujas identidades ou vivências entram em choque com as expectativas tradicionais e hegemônicas de performance de gênero e sexualidade. Assim, travestis e transexuais possuem taxas elevadas de evasão escolar em razão de fatores que vão da violência física e moral perpetrada por colegas, até violência institucional em razão da imposição do uso de banheiros, uniformes e nome com os quais o sujeito não se

50 LINS, Beatriz Accioly; MACHADO, Bernardo Fonseca; ESCOURA, Michele. Diferentes, não Desiguais: a questão de gênero na escola. São Paulo: Reviravolta, 2016,p. 9; JUNQUEIRA, Rogério Diniz. "Pedagogia do armário e currículo em ação: heteronormatividade, heterossexismo e homofobia no cotidiano escolar". In: MISKOLCI, Richard; PELÚCIO, Larissa (orgs.). Discursos fora da ordem: sexualidades, saberes e direitos. São Paulo: Annablume, Fapesp, 2012, pp. 288-289.

51 Por outro lado, em que pese a nova ordem constitucional - e mesmo a marcha da história - ao menos um exemplo renitente de instituição educacional somente para meninos resiste no Brasil: o Colégio São Bento, no Rio de Janeiro.

52 LINS, B. A.; MACHADO, B. F.; ESCOURA, M. Diferentes, não Desiguais. Op. Cit., pp. 22-23.

${ }_{53} \mathrm{MISKOLCl}, \mathrm{R}$. Teoria Queer. Op. Cit., p. 12.

54 JUNQUEIRA, R. D. "Pedagogia do armário e currículo em ação". Op. Cit., p. 281. 
identifica ${ }^{55}$.

De maneira geral, o conteúdo da diversidade sexual encontra-se ausente da preocupação institucional formal dos colégios e das diretrizes curriculares. O tema da sexualidade costuma aparecer na sala de aula somente sob o enfoque do controle social e do perigo, e não da valorização. Assim, o tratamento exclusivo na disciplina de biologia ou ciências ignora o conteúdo social e histórico da sexualidade, muitas vezes relegando o tema à reprodução/contracepção (invisibilizando práticas sexuais não reprodutivas) ou às DSTs (criando um discurso higienista de repressão sexual) ${ }^{56}$. Não se trata de defender que estes temas são desimportantes, mas da percepção de que "reduzir a sexualidade, o desejo e o prazer a imperativos de saúde pública pode ser uma forma de violência com relação aos diferentes anseios individuais" ${ }^{17}$. Desta forma, o tratamento da sexualidade em sala de aula invisibiliza a homossexualidade ao mesmo tempo em que elege a heterossexualidade reprodutiva (pênis-vagina) como única vivência saudável ${ }^{58}$.

Se no campo do currículo formal se observa uma ausência e invisibilização dos debates em torno da diversidade sexual, no âmbito do chamado "currículo oculto" das escolas existe marcada reprodução e reforço da homofobia ${ }^{59}$. O processo de normalização

55 PERES, William Siqueira. "Cenas de exclusões anunciadas: travestis, transexuais e transgêneros e a escola brasileira". In: JUNQUEIRA, Rogério D. (Org.). Diversidade Sexual na Educação. MEC/Unesco, 2009. Bento crítica inclusive o uso do temo "evasão" neste caso, preferindo falar em "expulsão", na medida em que existe um verdadeiro desejo de eliminar os sujeitos que "contaminam" o ambiente escolar (BENTO, B. "Na escola se aprende que a diferença faz a diferença”. Op. Cit., p. 555).

${ }^{56}$ Segundo Diniz e Lionço: "a heteronormatividade se fundamento no discurso sobre a biologia humana, de modo a naturalizada os corpos e a relação sexual. Não há referências à dimensão social e simbólica da sexualidade, sendo a reprodução sexuada a tônica das discussões nos livros didáticos de ensino fundamental e médio" (LIONÇO, Tatiana; DINIZ, Debora. "Homofobia, silêncio e naturalização: por uma narrativa da diversidade sexual". In: LIONÇO, Tatiana; DINIZ, Debora. (Orgs.). Homofobia \& Educação: um desafio ao silêncio. Brasília: LetrasLivres, EdUnB, 2009, p. 54).

57 MISKOLCI, R. Teoria Queer. Op. Cit, pp. 47-48.

${ }^{58}$ ALMEIDA, Edson Leandro de. Escola sem Homofobia: a (re)produção da identidade sexual nos discursos escolares. (Dissertação de Mestrado). Programa de Pós-Graduação em Educação, Culturas e Identidades. Universidade Federal Rural de Pernambuco, Recife, 2016, p. 48. Sobre o tema da educação sexual, Elizeu de Souza aponta que: "é com base no matrimônio, como ápice da expressão sexual, que a escola veicula os valores sexuais através do controle e da "biologização" da sexualidade dos sujeitos através da autorrepressão, da culpabilidade e do não prazer, daí se negar ou tolerar a homossexualidade como expressão da diferença que foge do padrão de "normalidade". A "dessexualização" dos sujeitos vem culturalmente marcada pela biologização e pelos diferentes conceitos e conselhos morais que giram em torno da sexualidade, encerrando-a na procriação e na manutenção da espécie. Esvaziar a sexualidade do seu conteúdo central - prazer - é a tarefa básica adotada pela escola através da chamada "educação sexual". [...] A negação da ideia de prazer, transposta pelo dever na sociedade conservadora e pudica, caracteriza-se pelo sacrifício, pela obediência, disciplina, punição e resignação das condutas e posturas morais e sexuais dos sujeitos" (SOUZA, E. C. "Direitos humanos e diversidade sexual na escola". Op. Cit., p. 217).

${ }^{59} \mathrm{~A}$ noção de currículo oculto engloba todos os aspectos do ambiente escolar que, sem fazer parte do currículo oficial, explícito, contribuem para aprendizagens sociais relevantes. Assim, por exemplo, as relações entre aluno e professor, entre os alunos, a organização do espaço escolar, as normas 
muitas vezes ocorre nessa esfera curricular "informal" - ainda que sob a complacência das instâncias formais/oficiais - que ensina àqueles que se desviam do que é considerado "normal", não raro de forma dolorosa, o seu lugar no mundo. Se, como aponta Eribon, a injúria é central na subjetivação homossexual ${ }^{60}$, a experiência escolar assume um papel crucial dentro deste processo. Não por acaso, Junqueira afirma a existência no âmbito escolar de uma "pedagogia do insulto", formada por uma miríade de violências e desumanizações, que produziriam uma "pedagogia do armário", entendida como um dispositivo de silenciamento e invisibilização ${ }^{61}$. Parte importante deste "currículo oculto" é o bullying praticado pelos alunos - embora não apenas por eles - contra outros alunos considerados desviantes de gênero, especialmente os meninos. A construção da subjetivação masculina é em grande medida formada a partir da recusa do feminino, e a violência contra um colega afeminado ("viadinho") é uma forma dos meninos reafirmarem a sua própria virilidade ${ }^{62}$.

Por outro lado, em que pese atuar muitas vezes no reforço de uma realidade desigual, como visto, a escola também pode ser um agente valioso de transformação e emancipação. Significa dizer, "essa mesma escola que, cotidianamente cultiva e ensina preconceitos e discriminações também é um espaço privilegiado para a crítica, a problematização de mecanismos de reificação e marginalização e de crenças e atitudes desumanizantes" ${ }^{\prime 63}$. Dito de outra forma, é possível conceber uma escola mais tolerante, democrática e pluralista, na qual a prática educacional - seja por meio do currículo formal, seja pelos componentes subterrâneos do currículo oculto - esteja em consonância com os deveres previstos pela ordem constitucional de 1988 no tocante às políticas de reconhecimento.

Importante destacar que a Constituição estabelece no art. 205 que o objetivo da educação é - nesta ordem - o "pleno desenvolvimento da pessoa, seu preparo para o exercício da cidadania e sua qualificação para o trabalho". De igual forma, a Lei de Diretrizes e Bases da Educação (Lei no 9.394/96), embora seja silente quanto à diversidade sexual, propõe uma educação voltada à tolerância e ao pluralismo e a formação ética e de solidariedade humana dos estudantes. Significa dizer, mais do que uma mera instância

disciplinares, etc. (JUNQUEIRA, R. D. "Pedagogia do armário e currículo em ação". Op. Cit, pp. 277278)

60 ERIBON, D. Reflexões sobre a questão gay. Op. Cit., pp. 27-29.

61 JUNQUEIRA, R. D. “Pedagogia do armário e currículo em ação". Op. Cit, pp. 284-287.

62 BARRETO, Ana Luiza Cruz Sá. A escola e o seu papel na construção de diferentes identidades sociais. (Dissertação de Mestrado). Curso de Mestrado em Psicologia. Centro Universitário de Brasília, Brasília, 2016, p. 99.

63 JUNQUEIRA, R. D. “Pedagogia do armário e currículo em ação”. Op. Cit,, p. 279. 
tecnocrática de apreensão do conteúdo do currículo formal, a escola é entendida no ordenamento brasileiro como espaço central na construção da cidadania e no desenvolvimento das capacidades individuais. Uma escola que não está dedicada à prática da tolerância e à valorização do pluralismo subverte estes comandos ao frustrar, por exemplo, o desenvolvimento das capacidades dos alunos submetidos à "pedagogia do insulto" e à "pedagogia do armário" 64 .

Assim, algumas medidas podem ser levantadas para a transformação do papel da escola. A primeira delas diz respeito à inclusão no currículo formal de debates acerca da diversidade sexual, buscando conscientizar os alunos a respeito do tema e promover uma cultura de tolerância ${ }^{65}$. Neste sentido, acabar com o monopólio da biologia sobre a discussão da sexualidade, passando a tratar o tema de maneira transversal/interdisciplinar - ou ao menos confrontar o atual paradigma heteronormativo-reprodutivo da educação sexual - pode ajudar na "desnaturalização" da heterossexualidade como único modelo legítimo de sexualidade. Uma questão importante diz respeito à preocupação com o tema da diversidade sexual no material pedagógico utilizado em sala de aula. Analisando os livros didáticos adotados pelo "Programa Nacional do Livro Didático", Lionço e Diniz apontam um cenário não apenas de ausência do tema, como também de marcado reforço da heteronormatividade das relações sociais e de redução da sexualidade ao seu componente biológico e reprodutivo ${ }^{66}$. Ainda sobre a questão do livro didático, Rios e Santos apontam que, embora as diretrizes do Ministério da Educação tenham conseguido eliminar estereótipos e preconceitos explícitos dos livros didáticos adotados no âmbito do programa nacional, estas não foram capazes de efetivamente inserir em suas páginas uma discussão propositiva sobre o reconhecimento da diversidade sexual ${ }^{67}$. Em razão destes

64 TEIXEIRA, Adla Betsaida Martins; FREITAS, Marcel de Almeida. “Homofobia e misoginia na escola: enfrentamento a partir dos direitos humanos". In: Teoria \& Sociedade, no 21.2, 2013, p. 293.

$65 \mathrm{Um}$ precedente interessante no ordenamento brasileiro foi a inclusão por meio das leis no 10.630/03 e 11.645/08 da obrigatoriedade de que a temática da história e cultura afro-brasileira e indígena passasse a integrar transdisciplinarmente o currículo oficial, como uma medida de reconhecimento que visa desconstruir uma visão eurocêntrica de mundo.

${ }^{66}$ LIONÇO, T.; DINIZ, D. "Homofobia, silêncio e naturalização". Op. Cit., pp. 52-53. Por uma série de motivos que serão melhor abordados na seção seguinte, mesmo o tratamento da sexualidade nos moldes tradicionais pode ser um tema espinhoso, conforme atesta o recente episódio em que um grupo de pais de alunos de uma escola municipal de Ji-Pará, Rondônia, realizou um abaixo assinado pretendendo retirar das salas de aula um livro didático de ciências que apresentava um desenho de um pênis ereto. Sobre o caso, confira-se as instigantes reflexões de Eliane Brum: (BRUM, Eliane. “Escola Sem Pinto". El País. Opinião. Publicado em 17.04.2017. Disponível em <http://brasil.elpais.com/brasil/2017/04/17/opinion/1492435392_872941.html>. Acesso em 21.04.2017).

67 RIOS, Roger Raupp; SANTOS, Wederson Ruffino dos. "Diversidade sexual, educação e sociedade: reflexões a partir do Programa Nacional do Livro Didáticoln: LIONÇO, Tatiana; DINIZ, Debora. (Orgs.). Homofobia \& Educação: um desafio ao silêncio. Brasília: LetrasLivres, EdUnB, 2009, p. 147. 
silenciamentos, o debate sobre homofobia e diversidade sexual quando ocorre resulta da iniciativa individual de educadores interessados na temática.

Outra medida essencial relacionada à anterior diz respeito à necessidade de políticas de formação de professores específicas para a superação da homofobia como uma prática "normal" do cotidiano escolar ${ }^{68}$. Estas políticas devem contemplar, em primeiro lugar, a conscientização dos educadores acerca da diversidade sexual e o incentivo para que debatam o tema dentro da sala de aula, abordando a sexualidade para além da perspectiva biologizante e normalizadora e valorizando uma abordagem interdisciplinar, como forma de promover uma educação mais inclusiva e tolerante ${ }^{69}$. Por outro lado, deve-se também preparar os profissionais da educação para reconhecer e intervir em situações de homofobia. Com efeito, a "pedagogia do insulto" muitas vezes conta com a condescendência ou mesmo cumplicidade institucional; professores e diretores fazem vista grossa ao bullying homofóbico ou quando as violências se tornam impossíveis de ignorar promovem a culpabilização da vítima ${ }^{70}$.

Finalmente, a revisão de uma estrutura escolar altamente generificada poderia levar os alunos a questionar a própria estratificação dos papéis de gênero para além dos muros do colégio. Assim, por exemplo, é possível evitar o recurso organizacional da divisão entre "meninos" e "meninas", disponibilizar as mesmas atividades a todos os alunos, respeitar a identidade de gênero dos alunos no acesso às instalações e na escolha do uniforme ${ }^{71}$, entre outros. Neste sentido, os professores e profissionais da educação de maneira geral têm um papel fundamental na construção e na manutenção dessa estrutura altamente estratificada e estereotipada de gênero no ambiente escolar ${ }^{72}$, devendo os programas de formação abordarem também essa questão.

A principal política pública federal de reconhecimento neste tema foi o Projeto “Escola sem Homofobia”, lançado em 2011, e que tinha por objetivo efetivar as ações

68 SOUZA, E. C. "Direitos humanos e diversidade sexual na escola". Op. Cit., p. 206; ALMEIDA, E. L. Escola sem Homofobia. Op. Cit., p. 49.

${ }^{69}$ Sobre o tema, o Estatuto da Juventude (Lei no 12.852/2012), uma das poucas leis do ordenamento brasileiro a fazer referência expressa à orientação sexual, prevê em seu art. 17, II, dentre as medidas a serem adotadas pelo poder público "na efetivação do direito do jovem à diversidade e à igualdade", a "inclusão de temas sobre questões étnicas, raciais, de deficiência, de orientação sexual, de gênero e de violência doméstica e sexual praticada contra a mulher na formação dos profissionais de educação".

70 RIOS, R. R.; SANTOS, W. R. "Diversidade sexual, educação e sociedade". Op. Cit., p. 144; TEIXEIRA, A. B. M.; FREITAS, M. A. "Homofobia e misoginia na escola”. Op. Cit., p. 298; BARRETO, A. L. C. S. A escola e o seu papel na construção de diferentes identidades sociais. Op. Cit., p. 101.

${ }^{71}$ Recentemente o Colégio Pedro II, no Rio de Janeiro adotou o fim da divisão por gênero do tradicional uniforme do colégio - calças para meninos e saias para as meninas - de forma que os alunos possam escolher qual peça do uniforme melhor retrata sua identidade de gênero.

72 SOUZA, E. C. "Direitos humanos e diversidade sexual na escola". Op. Cit., p. 205. 
previstas no Programa "Brasil sem Homofobia", de 200473. O projeto "Escola sem Homofobia" envolveu vários Ministérios, com destaque para os da Saúde e da Educação, além de contar com participação de representantes da sociedade civil e da academia ${ }^{74}$. Embora envolvesse uma série de iniciativas ${ }^{75}$, a política ficou famosa pelo "kit" de materiais impressos e audiovisuais que visava incentivar o debate dos temas da diversidade sexual e de identidade de gênero junto aos estudantes dos últimos anos do fundamental e do ensino médio pelos professores e escolas interessados ${ }^{76}$. Tal "kit", entretanto, foi vetado e recolhido pela Presidência da República após ser questionado por políticos conservadores, conforme será abordado na próxima seção.

Segundo Nancy Fraser, os remédios de reconhecimento e de redistribuição que visam o enfrentamento das respectivas injustiças podem se basear em estratégias afirmativas e transformativas. Os remédios baseados em estratégias afirmativas buscam corrigir as injustiças decorrentes dos arranjos sociais sem mexer nas estruturas sociais que os produzem, enquanto as estratégias transformativas pretendem justamente a transformação profunda das estruturas sociais produtoras da injustiça. A autora entende que as políticas transformativas são preferíveis às meramente afirmativas, embora sejam mais difíceis de implementar na prática ${ }^{77}$. Neste sentido, Fraser defende a via media da "reforma não-reformista", que seriam medidas aparentemente afirmativas, mas que cumulativamente possuem o potencial de gerar, a longo prazo, efeitos transformativos ${ }^{78}$.

De acordo com esta classificação, é possível perceber que a escola e a educação têm um potencial transformativo capaz questionar as próprias bases sobre as quais se estrutura a homofobia. Os distintos mecanismos concretos sugeridos, como a inclusão do tema da diversidade sexual no currículo oficial ou a "desgenerificação" do ambiente escolar possuem, no mínimo, a capacidade de promover uma "reforma não-reformista". A intervenção na educação, espaço privilegiado de subjetivação e construção da cidadania e

73 O Programa "Brasil sem Homofobia" incluiu uma miríade de políticas e iniciativas, organizadas em onze eixos temáticos transversais, incluindo um especifico acerca do direito à educação (Conselho Nacional de Combate à Discriminação. Brasil Sem Homofobia: Programa de combate à violência e à discriminação contra GLTB e promoção da cidadania homossexual. Brasília: Ministério da Saúde, 2004, pp. 22-23. Disponivel em: <http://bvsms.saude.gov.br/bvs/publicacoes/brasil_sem_homofobia.pdf>. Acesso em: 21.04.2017).

${ }^{74}$ ALMEIDA, E. L. Escola sem Homofobia. Op. Cit., pp. 57-58.

75 Uma iniciativa relevante foi a capacitação de profissionais da educação, que atuaram como multiplicadores em suas respectivas escolas da política pública. Foram realizadas seis rodadas de capacitação com cerca de 200 profissionais (VITAL, Christina; LOPES, Paulo Victor Leite. Religião e Política: uma análise da atuação dos parlamentares evangélicos sobre direitos das mulheres e de LGBTs no Brasil. Rio de Janeiro: Fundação Heinrich Böll, 2012, p. 203).

76 Ibidem, pp. 110-111 e 200-203.

77 FRASER, N. "Social Justice in the Age of Identity Politics. pp. 74-78.

78 Ibidem. pp. 79-80. 
normas sociais, possui uma capacidade remedial das desigualdades culturais que vai muito além da meramente afirmativa. É justamente por este motivo que se afirma que a escola é um espaço privilegiado de enfrentamento da homofobia.

Diante deste quadro, deve ser criticada a prevalência que a criminalização adquiriu junto ao movimento LGBT organizado como principal bandeira de enfrentamento da homofobia. O recurso ao direito penal, por vezes encarado como uma panaceia para todos os males, mesmo diante de realidade sociais extremamente complexas, é visto com reservas por alguns setores da militância, a partir da crítica à criação de novos tipos penais e ao inchaço do Estado Penal ${ }^{79}$, ele mesmo produtor de intensa desigualdade; e da ideia de que outros mecanismos - como a própria educação - seriam mais efetivos ao enfrentamento e desconstrução do preconceito ${ }^{80}$. Assim, Borrillo entende que anteriormente à repressão da homofobia, é necessária uma atuação pedagógicopreventiva que modifique a forma pela qual a diversidade sexual é encarada socialmente, sem a qual criminalização restaria destituída de sentido ${ }^{81}$. Ademais, dentro da taxonomia proposta por Fraser, parece evidente que a criminalização se configura como uma resposta meramente afirmativa ao problema da homofobia, uma vez que não pretende desconstruir as estruturas que a produzem, mas tão somente intervir ex post facto numa situação de discriminação manifesta.

79 AGUIÃO, Silvia; VIANNA, Adriana; GUTTERRES, Anelise. "Limites, espaços e estratégias de participação do movimento LGBT nas políticas governamentais". In: LOPES, José Sergio Leite; HEREDIA, Beatriz (orgs.). Movimentos Sociais e Esfera Pública: o mundo da participação. Rio de Janeiro, CBAE, 2014, p. 253. Por outro lado, Vecchiatti, um dos principais defensores da criminalização da homofobia, denuncia nestes discursos um "minimalismo penal seletivo", que só valeria para a proteção de pessoas LGBT, resultando na "hierarquização de opressões" em relação a outros grupos estigmatizados já contemplados na lei penal (VECCHIATTI, Paulo Roberto lotti. "Fundamentos em prol da Criminalização da Homofobia e da Transfobia". Jota. Publicado em 07.07.2016. Disponível em <https://jota.info/artigos/fundamentos-em-prol-da-criminalizacao-dahomofobia-e-da-transfobia-07072016>. Acesso em 21.04.2017).

${ }^{80}$ Assim, por exemplo, Jean Wyllys: "Acredito que não é apenas pela via do direito penal que iremos erradicar a homofobia e creio que o aumento do Estado penal, inclusive nesses casos, não é boa ideia [...] Precisamos de programas contra o bullying nas escolas, de campanhas nacionais contra o preconceito, de investimento público em favor da diversidade, de uma legislação que permita as pessoas se defenderem da discriminação no trabalho, no acesso aos serviços públicos e em outros âmbitos da vida social. Precisamos, enfim, de uma forte e decidida ação dos poderes públicos no sentido de erradicar a violência homofóbica e todas as formas de discriminação legal que a legitimam" (WYLLYS, Jean. Tempo Bom, Tempo Ruim: identidades, políticas e afetos. São Paulo: Paralela, 2014, pp. 81-82).

${ }^{81}$ BORRILLO, D. Homofobia. Op. Cit. p. 106.

Revista Publicum

Rio de Janeiro, v. 3, n. 1, 2017, p. 157-189.

http://www.e-publicacoes.uerj.br/index.php/publicum

DOI: 10.12957/publicum.2017.27322 


\section{Disputas e tensões}

Em que pese a exortação constitucional de intervenção do Estado para a transformação da realidade social com vistas à desconstrução dos padrões socioculturais produtores da homofobia, e da preponderância que a educação e escola assumem neste quadro, tal enfrentamento encontra significativa resistência de forças conservadores em prol da manutenção do status quo. Estes agentes disputam significados constitucionais na defesa de uma pauta moral que visa o reforço e não a desconstrução destes padrões.

A bandeira da "defesa da família" é o guarda-chuva retórico dentro do qual se inclui boa parte dos itens da agenda do conservadorismo moral em temas como direitos das mulheres e de LGBT e legalização das drogas. O que esta bandeira pretende, na verdade é a defesa de uma concepção única e exclusiva de família como "natural" ou moralmente aceitável. Este modelo tradicional de família é justamente aquele marcado pela estratificação de papéis de gênero e hierarquização de vivências sexuais responsáveis pela produção da homofobia. Esta pauta do "moralismo sexual" na política é reivindicada especialmente pelos agentes religiosos, sobretudo católicos e evangélicos.

A influência da religião no debate político nacional, embora não seja um processo recente, ganha destaque a partir dos anos 1990 com a ocupação direta de cargos no legislativo de religiosos ligados a igrejas cristãs, principalmente neopentecostais ${ }^{82}$. Estes parlamentares têm uma agenda baseada na "defesa da família" e uma alta capacidade organizacional, formando um bloco coeso estruturado na forma de uma frente parlamentar, comumente chamada de "bancada evangélica" ${ }^{83}$. Ao se apresentarem enquanto um grupo de poder expressivo dentro do Congresso Nacional, esses parlamentares ligados diretamente às religiões detém grande capacidade de negociação na formulação das políticas públicas federais dentro do sistema brasileiro de "presidencialismo de coalizão"84.

82 MIGUEL, Luis Felipe. “Da 'doutrinação marxista' à 'ideologia de gênero': Escola sem Partido e as leis de mordaça no parlamento brasileiro". In: Direito \& Práxis. Rio de Janeiro, Vol. 07, no 15, 2016, p. 593. Vital e Lopes denominam esse processo de "confessionalização da política" (VITAL, C.; LOPES, P. V. L. Religião e Política. Op. Cit., p. 171).

83 Ibidem, pp. 156 seq.

${ }^{84}$ Ibidem, p. 9. A ideia de "presidencialismo de coalizão" visa retratar o modelo político brasileiro, em que há uma ampla fragmentação de poder no Legislativo, decorrente principalmente da pulverização partidária. Esta circunstância obriga o Executivo a costurar alianças com grupos políticos muito distintos para a formação da maioria parlamentar necessária à aprovação de leis e emendas constitucionais de interesse do governo, formando uma base de sustentação ideologicamente heterogênea, o que seria responsável pela produção de instabilidade e disputas internas. Assim, por exemplo, os governos petistas, embora encarados como de esquerda ou centroesquerda, formularam alianças com legendas de direita e centro-direita, como PR, PP e PSC, em prol da governabilidade. 
Diante deste quadro, as políticas públicas de educação adquirem papel central na preocupação dos grupos políticos de "defesa da família", em razão de uma série de fatores, como por exemplo, a efetiva capacidade das políticas de reconhecimento nesta seara minarem suas bases de sustentação, conforme trabalhado anteriormente. Ademais, diante do tabu do sexo e especificamente da sexualidade juvenil, denunciar a inserção do tema da sexualidade no universo escolar pode disparar pânicos morais e, desta forma, ser politica e eleitoralmente vantajoso. A própria definição dos contornos da relação entre a educação e as visões religiosas é um dos pontos de tensão do princípio da laicidade de mais difícil equacionamento dentro da Constituição de 1988, que previu expressamente a obrigação de oferta de ensino religioso, embora de matrícula facultativa, no art. 210, $\S 10^{085}$.

Uma das mais conhecidas exibições de musculatura política da "bancada evangélica" envolveu justamente uma política pública educacional de combate à homofobia. Trata-se do episódio da suspensão pelo Governo Federal do material didático do projeto "Escola Sem Homofobia" em 2011, comumente referido pelo apelido dado pelos seus detratores de "kit gay". Após intensa pressão dos setores religiosos e parlamentares da extrema-direita, que ameaçavam convocar o então Ministro da Casa Civil Antonio Palocci para explicar no Congresso sua contestada evolução patrimonial, a Presidente Dilma Rousseff suspendeu o projeto sob o argumento de que o governo não faria "propaganda de opções sexuais" ${ }^{86}$.

O principal artifício retórico deste conservadorismo religioso no campo educação foi a formulação da noção de "ideologia de gênero", ideia de que ganhou força principalmente durante o longo debate para a aprovação do novo Plano Nacional de Educação - PNE (Lei no 13.005/2014), e os planos estaduais e municipais posteriormente ${ }^{87}$. Partindo de uma leitura enviesada, simplificadora ou mesmo caricatural

${ }^{85}$ Embora a previsão seja complementada pelo art. 33 da Lei de Diretrizes e Bases (Lei no 9.304/96), a forma específica pela qual deve se dar a concretização da norma constitucional é objeto de intenso debate no âmbito do direito, estando a questão pendente de definição pelo STF na ADI no 4.439 . Sobre o tema, vide: DINIZ, D.; LIONÇO, T. "Educação, direitos sexuais, laicidade e diversidade sexual". Op. Cit.; PEREIRA, Jane Reis Gonçalves. "A aplicação de regras religiosas de acordo com a lei do Estado: um panorama do caso brasileiro". In: Revista da AGU, v. 41, 2014, pp. 20 et seq. e SARMENTO, Daniel. "Ensino religioso nas escolas públicas". Jota. Publicado em 23.06.2015. Disponível em <https://jota.info/artigos/ensino-religioso-nas-escolas-publicas-23062015>. Acesso em 21.04.2017.

86 VITAL, C.; LOPES, P. V. L. Religião e Política. Op. Cit, pp. 131 et seq.

87 SOUZA, Sandra Duarte. “'Não à ideologia de gênero!': a produção religiosa da violência de gênero na política brasileira". In: Estudos da Religião, v. 28, n. 2, 2014, pp. 192 et seq; MIGUEL, L. F. "Da 'doutrinação marxista' à 'ideologia de gênero'”. Op. Cit., p. 599. Assim, durante os debates para aprovação do PNE no Senado Federal o inciso II do art. 2ㅇ do projeto de lei, que prevê as suas diretrizes, teve sua redação alterada, retirando a ênfase na promoção de "igualdade racial, regional, 
das discussões do feminismo e da teoria queer ${ }^{88}$ defende-se que a discussão do gênero como produção cultural representaria uma subversão da sexualidade e da família naturais, atuando fortemente na defesa de sentidos dominantes de sexo e família, por meio de um discurso essencialista e biologizante ${ }^{89}$. Neste sentido, imbricam-se argumentos religiosos e pseudo-científicos a respeito da sexualidade, a partir da ideia de que os comportamentos saudáveis e naturais seriam aqueles praticados dentro da família heterossexual e cristã, enquanto as formas desviantes de sexualidade são retratadas simultaneamente como pecaminosas, antinaturais e patológicas. Para seus opositores, a propalada "ideologia de gênero" representaria "uma ameaça única, indistinta, de subversão dos arranjos familiares que são vistos, a um só tempo, como naturais, de origem divina e indispensáveis à reprodução da vida social” ${ }^{90}$. Ademais, por meio do acionamento do pânico moral da sexualidade infantil defende-se que as crianças e adolescentes seriam mais vulneráveis a esta influência perniciosa, razão pela qual o tema ganhou centralidade no debate da educação. Outra estratégia envolve substituir o objetivo de construção da tolerância e respeito à diversidade das políticas educacionais pelo de incentivar ou fomentar o "homossexualismo" e mesmo a pedofilia ${ }^{91}$ ou de perseguição e intolerância em face da religiosidade cristã ${ }^{92}$.

A partir de 2010 as forças conservadoras presentes no congresso nacional começam a se aliar na defesa conjunta de suas propostas para a educação. Assim, o discurso da "ideologia de gênero" entra em concerto com a defesa da chamada "Escola sem Partido". O "Movimento Escola sem Partido" foi fundado em 2004, mas ganhou projeção mais recentemente, quando suas bandeiras começaram a ser abraçadas por

de gênero e de orientação sexual" para a referência mais anódina do texto final a "todas as formas de discriminação" (SANTIAGO, Mylene Cristina; SANTOS, Mônica Pereira dos; MELO, Sandra Cordeiro de. "Plano Nacional de Educação (2014-2024): considerações omniléticas sobre o patrulhamento ideológico e as diferenças silenciadas". In: Revista Educação e Cultura Contemporânea, v. 13, n. 22, 2016, p. 68).

88 Ibidem, pp. 596-598.

89 SOUZA, S. D. “'Não à ideologia de gênero!'”. Op. Cit., p. 197. Lopes questiona a ideia da defesa de uma sexualidade "natural" em oposição a outra "antinatural" questionando a própria noção do que é natural. Se entendermos que natural é aquilo que existe na natureza, comportamentos homossexuais são observados em uma série de outras espécies animais. Por outro lado, se natural significar "em acordo com as finalidades da natureza", existe o problema que a natureza não é prescritiva, e sim determinante (LOPES, J. R. L. "O direito ao reconhecimento para gays e lésbicas". Ibidem, pp. 80-81. Deve-se acrescentar, ainda, que falar em "família natural" parece um contrassenso evidente, uma vez que a não há dúvida que a entidade e os arranjos familiares são construções históricas.

90 MIGUEL, L. F. "Da 'doutrinação marxista' à 'ideologia de gênero'”. Op. Cit., p. 597. Neste sentido, Natividade e Oliveira destacam o recurso do discurso religioso à uma concepção de mundo naturalista, como forma de sustentar a evidência e universalidade de seus preceitos (NATIVIDADE, M; OLIVEIRA, L. As novas guerras sexuais. Op. Cit., p. 11).

${ }^{91}$ VITAL, C.; LOPES, P. V. L. Religião e Política. Op. Cit, p. 152.

92 NATIVIDADE, M; OLIVEIRA, L. As novas guerras sexuais. Op. Cit., p. 114. 
políticos conservadores ${ }^{93}$. O ponto central do movimento é a ideia de que professores estariam promovendo uma "doutrinação ideológica", ligada a bandeiras de esquerda, ao comunismo e ao PT, em razão da qual buscam a defesa de uma educação "neutra", que respeite a integridade moral dos estudantes e o direito dos pais de dar aos filhos uma educação que esteja de acordo com as suas próprias convicções ${ }^{94}$.

Com a aliança entre as duas pautas - da "ideologia de gênero" e da "Escola sem Partido" - o debate passou a ser feito num âmbito mais geral entre a disputa da autoridade escolar em face da autoridade da família sobre a formação moral e política das crianças, a partir da ideia de que os pais deveriam ter o poder de vetar a discussão em sala de aula de temas contrários aos seus valores ${ }^{95}$. Uma série de projetos de lei tanto na Câmara, quanto no Senado tem buscado promover em maior ou menor medida as ideias do "Escola sem Partido" ou do enfrentamento da "ideologia de gênero" ${ }^{96}$. Ademais, propostas semelhantes têm sido introduzidas em diversos Estados e Municípios, algumas das quais lograram aprovação pelos legislativos locais ${ }^{97}$. Com efeito, o site do "Movimento Escola Sem Partido" possui "projetos modelo" de lei estadual e municipal para serem apresentados por vereadores e deputados interessados, que contemplam expressamente a discussão de gênero e sexualidade ${ }^{98}$.

Todas estas propostas se baseiam em dois pilares: o da soberania da família, que defende uma concepção de que esta seria uma entidade dotada de direitos independentes daqueles da individualidade dos seus membros, com a preponderância dos

93 MIGUEL, L. F. “Da 'doutrinação marxista' à 'ideologia de gênero'”. Op. Cit., p. 595.

${ }^{94}$ AMORIM, Marina; SALEJ, Ana Paula. "O conservadorismo saiu do armário: a luta contra a ideologia de gênero do movimento escola sem partido". In: Revista Ártemis, vol. XXII, no 1, 2016, p. 33.

95 MIGUEL, L. F. "Da 'doutrinação marxista' à 'ideologia de gênero'”. Op. Cit., pp. 596 e 601. Esta bandeira da autoridade parental costuma ser lastreada no art. 12.4 da Convenção Americana sobre Direitos Humanos (Pacto San José da Costa Rica) segundo o qual "Os pais, e quando for o caso os tutores, têm direito a que seus filhos ou pupilos recebam a educação religiosa e moral que esteja acorde com suas próprias convicções".

${ }^{96}$ Para uma relação completa dos projetos e seus escopos individuais vide MIGUEL, L. F. "Da 'doutrinação marxista' à 'ideologia de gênero'”. Op. Cit., pp. 604 et seq, e SANTIAGO, M. C.; SANTOS, M. P.; MELO, S. C. "Plano Nacional de Educação (2014-2024)". Op. Cit., pp. 73 et seq.

${ }^{97}$ Assim, por exemplo, a Lei Municipal no 5.165/2015, de Volta Redonda, que vedava "a implantação da política de ideologia de gênero nos estabelecimentos de ensino do Município de Volta Redonda", recentemente declarada inconstitucional pelo Tribunal de Justiça do Estado do Rio de Janeiro (Representação de Inconstitucionalidade № 0007584-60.2016.8.19.0000), que aduziu que " adotarse posição proibitiva à informação e ao diálogo, chancelaria tratamento discriminatório, criando entraves à promoção da cidadania e a igualdade, em afronta a Constituição do Estado e a Constituição Federal. Inconteste, pois, que a Câmara Municipal de Volta Redonda, ao editar a referida norma jurídica, vedando a implantação da política de ideologia de gênero nos estabelecimentos de ensino do Município de Volta Redonda, violou, de uma só tacada, o princípio constitucional da igualdade no aspecto estrutural (direito a não discriminação), o direito fundamental à diferença, o modelo republicano do Estado brasileiro, baseado no pluralismo político, e o princípio da laicidade estatal".

${ }_{98}$ AMORIM, M.; SALEJ, A. P. “O conservadorismo saiu do armário”. Op. Cit., pp. 33-34. 
pais sobre os filhos ${ }^{99}$; e o da neutralidade do ensino, entendendo que o professor deveria meramente "passar o conteúdo" sem qualquer ilação de ordem crítica ou pessoal.

A "soberania da família" é utilizada na tentativa de vedar o debate na escola dos temas da diversidade sexual e, consequentemente, a adoção de propostas de enfrentamento da homofobia. Isto porque esta ideia tem por base a defesa da primazia da família em detrimento da escola para qualquer debate de ordem "moral", o que acaba por impedir uma educação que contribua com valores de tolerância e respeito às diferenças. Trata-se de uma disputa acerca das fronteiras entre o "público" e o "privado". Por outro lado, o debate sobre gênero e diversidade sexual é encarado como mais uma estratégia de destruição da "família natural" (i.e. patriarcal e heteronormativa). Se a família tradicional e os papéis de gênero são absolutos e imutáveis, seja pelo argumento "científico", seja pelo argumento religioso, não há possibilidade para discussão, uma vez que "a ordem natural e divina é, por definição, incontestável" 100.

A defesa da neutralidade do ensino, por sua vez, pretende reduzir a atividade de ensino à transmissão quase mecânica pelo professor de conteúdos objetivos, sem críticas e contextualizações, ignorando a interação entre o docente e seus alunos, entendidos como meros receptores e sujeitos passivos do processo educacional. Em primeiro lugar, essa noção ignora que o conhecimento é necessariamente localizado, de tal forma que a pretendida neutralidade sequer é possível, uma vez que mesmo a mera seleção de que conteúdos objetivos serão transmitidos implica em escolhas políticas. Em segundo lugar, a neutralidade incorre na cristalização de desigualdades e injustiças, uma vez que "projeta uma educação que é incapaz de intervir no mundo e, por isso, torna-se cúmplice das injustiças e das violências que nele ocorrem"101. Em sentido semelhante, Sarmento entende que por detrás da busca de uma suposta neutralidade muitas vezes se esconde a defesa da manutenção do status quo ${ }^{102}$. Assim, a neutralidade da educação em termos de gênero, sexualidade e concepções de família representa não a defesa de "modelo nenhum" e sim a defesa do modelo hegemônico ${ }^{103}$. Cabe questionar, portanto, em que

${ }^{99}$ Esta tensão entre a soberania da família de um lado e o Estado e a escola de outro já havia marcado os debates em torno da chamada Lei da Palmada ou Lei Menino Bernardo (Lei no 13.010/2014) que vedou o recurso à castigos físicos tanto nas escolas quanto nas famílias, reduzindo portanto a liberdade dos pais na educação dos seus filhos.

100 MIGUEL, L. F. “Da 'doutrinação marxista' à 'ideologia de gênero'”. Op. Cit., p. 613.

101 Ibidem, p. 615

102 SARMENTO, D. Dignidade da Pessoa Humana. Op. Cit. p. 173.

${ }^{103}$ Assim: "a escola é parte de uma sociedade em que há extrema desigualdade de gênero; portanto se não defender uma proposta pedagógica de intervenção nessas questões, ela somente reproduzirá injustiças, violências, discriminações, exclusões e marginalizações. A educação, se comprometida com a igualdade social e a inclusão, pode vir a ser um caminho privilegiado para a 
medida essa educação soi-disant neutra, mas que na realidade é localizada e opressora, atende aos próprios desígnios constitucionais de superação de padrões culturais produtores de desigualdade e injustiça ${ }^{104}$.

Essa defesa da neutralidade na educação, aliada à ideia de "soberania da família", pretende retirar os temas morais e "políticos" do âmbito da escola (público) e remetê-los à relação entre pais e filhos (privado). Uma primeira leitura poderia levar a crer que esta translação se ajusta às concepções liberais que valorizam a autonomia do indivíduo para decidir seus projetos existenciais em face da intromissão estatal. Esta perspectiva ignora, porém, que não existe real deferência à autodeterminação individual neste caso, uma vez que as escolhas são feitas pelos pais em nome dos filhos. Por outro lado, o fato de que de crianças e adolescentes são sujeitos em formação impõe determinadas modulações à sua capacidade de autodeterminação. Ademais, a Constituição de 1988 previu um projeto de intervenção ativa na realidade para a superação dos preconceitos e discriminações, o que coloca em xeque a defesa absoluta da neutralidade estatal. Assim, segundo Sarmento:

\begin{abstract}
A própria garantia da liberdade justifica que o Estado abandone a sua suposta neutralidade cosmovisiva para favorecer, em regra, sem coerções, compreensões de 'vida boa' cuja adoção pelas pessoas propicie um ambiente cultural mais hospitaleiro para o livre desenvolvimento da personalidade de cada integrante da sociedade. Se o exercício efetivo da liberdade por pessoas concretas é fortemente condicionado pela atmosfera cultural em que elas estão inseridas, como se assentou acima, me parece evidente que um Estado que valorize a autonomia individual não deve se manter indiferente em relação à cultura vigente ${ }^{105}$.
\end{abstract}

Assim, pode-se concluir que existe uma disputa em curso com relação ao papel que o Estado e a esfera pública de maneira geral devem assumir em face dos preconceitos e padrões culturais assimétricos frutos de visões religiosas ou morais "privadas". A escola

emancipação" (LINS, B. A.; MACHADO, B. F.; ESCOURA, M. Diferentes, não Desiguais. Op. Cit, pp. 101-102).

${ }^{104}$ Neste sentido: "ao incorporar ao vocabulário legislativo o termo 'ideologia de gênero', o MESP luta pelo veto ao uso dos termos "gênero" e "orientação sexual" no vocabulário escolar, querendo mesmo é evitar qualquer questionamento da percepção naturalizada dos papéis sexuais. Assim, quando levanta a bandeira da neutralidade, o movimento se refere a um discurso que não questiona o mundo como ele é e que bloqueia as potencialidades de mudanças. Sua ideia de neutralidade se baseia na ficção de um conhecimento que não é situado socialmente. Na realidade, essa neutralidade não existe, uma vez que toda produção de conhecimento parte de um lugar social específico (AMORIM, M.; SALEJ, A. P. "O conservadorismo saiu do armário". Op. Cit., p. 38).

105 SARMENTO, D. Dignidade da Pessoa Humana. Op. Cit., p. 174. Neste sentido, o autor dá um exemplo eloquente e assemelhado ao tema objeto do presente artigo: "O Estado não deve se manter neutro na disputa entre compreensões de mundo sexistas e igualitárias. Ele pode - deve preferir as segundas, e favorecê-las, por exemplo, na definição dos currículos escolares, nas suas políticas públicas, nos seus atos simbólicos. Deve fazê-lo para que a sociedade, como um todo, se torne um espaço mais propício para que pessoas reais e concretas possam vivenciar a sua liberdade, num ambiente cultural que não as oprima ou estigmatize" (Loc. Cit.).

Revista Publicum

Rio de Janeiro, v. 3, n. 1, 2017, p. 157-189.

http://www.e-publicacoes.uerj.br/index.php/publicum

DOI: 10.12957/publicum.2017.27322 
assume um papel central nessa tensão em razão do seu papel transformador preconizado pela Constituição de 1988, que coloca em xeque os limites e as localizações de uma suposta "neutralidade" que vem se defendendo que a educação deveria adotar diante de uma realidade desigual e da imposição de valores no seio das famílias ${ }^{106}$.

\section{Conclusão}

O presente artigo teve por objetivo analisar a contribuição que a escola pode dar a desconstrução de uma cultura marcada pela homofobia. Para tanto, em primeiro lugar verificou-se as bases culturais sobre as quais a mesma se erige: heterossexualidade compulsória, dominação masculina, cristalização de papéis de gênero, hierarquização entre masculino e feminino. Neste sentido, com esteio no pensamento da teórica Nancy Fraser, concluiu-se que a homofobia representa uma injustiça no campo cultural, a necessitar de políticas de reconhecimento para o seu enfrentamento, e que estas se configuram como uma exigência constitucional a partir da previsão da Carta de 1988 de construção de uma sociedade mais fraterna, pluralista e sem preconceitos.

Diante deste cenário, examinou-se como a escola detém um papel central na produção e reprodução da própria homofobia, mas também como pode desempenhar uma função diametralmente oposta. Assim, analisou-se o potencial que a educação possui para o questionamento e desconstrução de um modelo cultural produtor da homofobia, verificando-se ainda algumas medidas e formas concretas para tanto. A adoção de

106 Destaca-se que estas conclusões também foram perfilhadas pela Procuradoria Federal dos Direitos do Cidadão, órgão ligado à Procuradoria-Geral da República, na Nota Técnica 01/2016 PFDC, acerca da proposição legislativa que pretende implementar o "Programa Escola sem Partido", in verbis: "O que se revela, portanto, no PL e no seu documento inspirador é o inconformismo com a vitória das diversas lutas emancipatórias no processo constituinte; com a formatação de uma sociedade que tem que estar aberta a múltiplas e diferentes visões de mundo; com o fato de a escola ser um lugar estratégico para a emancipação política e para o fim das ideologias sexistas que condenam a mulher a uma posição naturalmente inferior, racistas - que representam os nãobrancos como os selvagens perpétuos, religiosas - que apresentam o mundo como a criação dos deuses, e de tantas outras que pretendem fulminar as versões contrastantes das verdades que pregam.

O PL subverte a atual ordem constitucional, por inúmeras razões: (i) confunde a educação escolar com aquela que é fornecida pelos pais, e, com isso, os espaços público e privado; (ii) impede o pluralismo de ideias e de concepções pedagógicas (art. 206, III); (iii) nega a liberdade de cátedra e a possibilidade ampla de aprendizagem (art. 206, II); (iv) contraria o princípio da laicidade do Estado, porque permite, no âmbito da escola, espaço público na concepção constitucional, a prevalência de visões morais/religiosas particulares.

Enfim, e mais grave, o PL está na contramão dos objetivos fundamentais da República Federativa do Brasil, especialmente os de 'construir uma sociedade livre, justa e solidária' e de 'promover o bem de todos, sem preconceitos de origem, raça, sexo, cor, idade e quaisquer outras formas de discriminação". (Procuradoria Federal dos Direitos do Cidadão. Nota Técnica 01/2016 PFDC. 21.07.2016. Disponível em: <http://pfdc.pgr.mpf.mp.br/temas-de-atuacao/educacao/saibamais/proposicoes-legislativas/nota-tecnica-01-2016-pfdc-mpf>. Acesso em 21.04.2017). 
políticas públicas educacionais que visem transformar as escolas em espaços emancipatórios de promoção da tolerância, por outro lado, é questionada por forças e movimentos conservadores que pretendem a conservação de um status quo, e que vêm fabricando a noção de "ideologia de gênero" como artifício retórico para se opor a atuação da escola no enfrentamento da homofobia.

Neste sentido, a discussão acerca do papel que a escola deve assumir diante da realidade da homofobia se insere num contexto geral de disputas de significados constitucionais entre grupos conservadores de "defesa da família" e grupos de defesa da diversidade sexual, cuja mobilização e debates em torno de suas bandeiras políticas ajuda a definir as políticas públicas efetivamente adotadas pelo Estado. Assim, Junqueira entende que:

\footnotetext{
A criação de condições para lidar de maneira adequada com os temas relativos à diversidade sexual e aos direitos sexuais nas escolas depende, em grande medida, de políticas públicas de educação e de mobilizações sociais que objetivem desestabilizar a produção de hierarquias, opressões $e$ clivagens concernentes tanto aos padrões heteronormativos, que historicamente modularam e modulam as relações de gênero, quanto às dinâmicas de (re)produção de diferenças e desigualdades ${ }^{107}$.
}

O presente artigo, é bom frisar, assume explicitamente um dos lados dessa disputa, defendendo que o mesmo é aquele exigido pela ordem constitucional de 1988. Mais do que isso, a adoção de políticas de reconhecimento no âmbito da escola é uma exigência de justiça nos termos da teoria de Nancy Fraser, uma vez que somente uma educação comprometida com a tolerância e o respeito à diversidade sexual, em que não haja uma "pedagogia da homofobia", pode produzir sujeitos comprometidos com padrões culturais de igual respeito e ajudar a produzir efetiva paridade de participação.

\section{Bibliografia}

AGUIÃO, Silvia; VIANNA, Adriana; GUTTERRES, Anelise. Limites, espaços e estratégias de participação do movimento LGBT nas políticas governamentais. In: LOPES, José Sergio Leite; HEREDIA, Beatriz (orgs.). Movimentos Sociais e Esfera Pública: o mundo da participação. Rio de Janeiro, CBAE, 2014, pp. 238-269.

ALMEIDA, Edson Leandro de. Escola sem Homofobia: a (re)produção da identidade sexual nos discursos escolares. (Dissertação de Mestrado). Programa de Pós-Graduação em Educação, Culturas e Identidades. Universidade Federal Rural de Pernambuco, Recife, 2016, p. 105.

107 JUNQUEIRA, R. D. “Políticas de educação para a diversidade sexual”. Op. Cit., p. 163. 
AMORIM, Marina; SALEJ, Ana Paula. O conservadorismo saiu do armário: a luta contra a ideologia de gênero do movimento escola sem partido. Revista Ártemis, vol. XXII, no 1, 2016, pp. 32-42.

BARROSO, Luís Roberto; OSÓRIO, Aline Rezende Peres. "Sabe com quem está falando?": Algumas notas sobre o princípio da igualdade no Brasil contemporâneo. 24p. Disponível em:

<http://www.luisrobertobarroso.com.br/wpcontent/themes/LRB/pdf/SELA_Yale_palestra _igualdade_versao_fina.pdf $>$. Acesso em: 21.04.2017.

BARRETO, Ana Luiza Cruz Sá. A escola e o seu papel na construção de diferentes identidades sociais. (Dissertação de Mestrado). Curso de Mestrado em Psicologia. Centro Universitário de Brasília, Brasília, 2016, p. 210.

BENTO, Berenice. Na escola se aprende que a diferença faz a diferença. Estudos Feministas, 19(2), 2011, pp. 548-559.

BORRILLO, Daniel. Homofobia: história e crítica de um preconceito. Belo Horizonte: Autêntica, 2010, p. 142.

BRASIL. Conselho Nacional de Combate à Discriminação. Brasil Sem Homofobia: Programa de combate à violência e à discriminação contra GLTB e promoção da cidadania homossexual. Brasília: Ministério da Saúde, 2004, 32p. Disponível em: <http://bvsms.saude.gov.br/bvs/publicacoes/brasil_sem_homofobia.pdf>. Acesso em: 21.04.2017.

BRUM, Eliane. “Escola Sem Pinto”. El País. Opinião. Publicado em 17.04.2017. Disponível em <http://brasil.elpais.com/brasil/2017/04/17/opinion/1492435392_872941.html>. Acesso em 21.04.2017.

BUTLER, Judith. Problemas de Gênero: feminismo e subversão da identidade. 8 a Ed. Rio de Janeiro: Civilização Brasileira, 2015, p. 287.

CARRARA, Sérgio. Políticas e direitos sexuais no Brasil contemporâneo. Bagoas, no 05, 2010, pp. 131-147.

CASTELLS, Manuel. O poder da identidade. 8a Ed. São Paulo: Paz e Terra, 1999, p. 530.

CASTRO, Carlos Roberto Siqueira. A nova dimensão da igualdade. In: CASTRO, Carlos Roberto Siqueira. Constituição Aberta e os Direitos Fundamentais: Ensaios sobre o constitucionalismo pós-moderno e comunitário. 2a Ed. Rio de Janeiro: Forense, 2010, pp. 357-435.

COHEN, Jean L. Repensando a privacidade: autonomia, identidade e controvérsia sobre o aborto. Revista Brasileira de Ciência Política, no 7. Brasília, janeiro/abril de 2012, pp. 165203.

DINIZ, Debora; LIONÇO, Tatiana. Educação, direitos sexuais, laicidade e diversidade sexual. In: In: RIOS, Roger Raupp; GOLIN, Célio; LEIVAS, Paulo Gilberto Cogo. Homossexualidade e 
Direitos Sexuais: reflexões a partir da decisão do STF. Porto Alegre: Sulina, 2011, pp. 125146.

ERIBON, Didier. Reflexões sobre a questão gay. Rio de Janeiro: Companhia de Freud, 2008, p. 455.

FRASER, Nancy. Social Justice in the Age of Identity Politics: Redistribution, Recognition, and Participation. In: FRASER, Nancy; HONNETH, Axel. Redistribution or Recognition?: a political-philosophical exchange. Londres: Verso, 2003. pp. 7-109.

Distorted Beyond All Recognition: A rejoinder to Axel Honneth. FRASER, Nancy; HONNETH, Axel. Redistribution or Recognition?: a political-philosophical exchange. Londres: Verso, 2004, pp. 198-236.

FRASER, Nancy. Repensando a questão do reconhecimento: superar a substituição e a reificação na política cultural. In: BALDI, César Augusto. (org.). Direitos Humanos na Sociedade Cosmopolita. Rio de Janeiro: Renovar, 2004, pp. 601-621.

FRASER, Nancy. Redistribuição, Reconhecimento e Participação: por uma Concepção Integrada de Justiça. In: SARMENTO, Daniel; IKAWA, Daniela; PIOVESAN, Flávia. (coords.). Igualdade, Diferença e Direitos Humanos. Rio de Janeiro: Lumen Juris, 2010, pp. 167-190.

FRY, Peter. Diferenças, desigualdade e discriminação. In. LIMA, Antonio Carlos de Souza (coord.). Antropologia \& Direito: temas antropológicos para estudos jurídicos. Rio de Janeiro/Brasília: Contra Capa, 2012, pp. 227-233.

JUNQUEIRA, Rogério Diniz. Homofobia: limites e possibilidades de um conceito em meio a disputas. Revista Bagoas, V.1, n.1, jul./dez. 2007, p. 22.

JUNQUEIRA, Rogério Diniz. Políticas de educação para a diversidade sexual: escola como lugar de direitos. In: LIONÇO, Tatiana; DINIZ, Debora. (Orgs.). Homofobia \& Educação: um desafio ao silêncio. Brasília: LetrasLivres, EdUnB, 2009, pp. 161-193.

JUNQUEIRA, Rogério Diniz. Pedagogia do armário e currículo em ação: heteronormatividade, heterossexismo e homofobia no cotidiano escolar. In: MISKOLCl, Richard; PELÚCIO, Larissa (orgs.). Discursos fora da ordem: sexualidades, saberes e direitos. São Paulo: Annablume, Fapesp, 2012, pp. 277-306.

LINS, Beatriz Accioly; MACHADO, Bernardo Fonseca; ESCOURA, Michele. Diferentes, não Desiguais: a questão de gênero na escola. São Paulo: Reviravolta, 2016, p.142.

LIONÇO, Tatiana; DINIZ, Debora. Homofobia, silêncio e naturalização: por uma narrativa da diversidade sexual. In: LIONÇO, Tatiana; DINIZ, Debora. (Orgs.). Homofobia \& Educação: um desafio ao silêncio. Brasília: LetrasLivres, EdUnB, 2009, pp. 47-71.

LOPES, José Reinaldo de Lima. O direito ao reconhecimento para gays e lésbicas. Sur Revista Internacional de Direitos Humanos, ano 2, Número 2, 2005, pp. 64-95.

MARMELSTEIN, George. Jurisprudência arco-íris: comentários à decisão do Supremo Tribunal Federal acerca das uniões homoafetivas. Revista Brasileira de Direito Constitucional-RBDC n. 17 - jan./jun. 2011, pp. 225-262. 
MIGUEL, Luis Felipe. Da 'doutrinação marxista' à 'ideologia de gênero': Escola sem Partido e as leis de mordaça no parlamento brasileiro. Direito \& Práxis. Rio de Janeiro, Vol. 07, no 15, 2016, pp. 590-621.

MISKOLCI, Richard. Teoria Queer: um aprendizado pelas diferenças. 2a Ed. Belo Horizonte: Autêntica, 2015, p. 82.

NATIVIDADE, Marcelo; OLIVEIRA, Leandro de. As novas guerras sexuais: diferença, poder religioso e identidades LGBT no Brasil. Rio de Janeiro: Garamond, 2013, p.304.

PERES, William Siqueira. Cenas de exclusões anunciadas: travestis, transexuais e transgêneros e a escola brasileira. In: JUNQUEIRA, Rogério D. (Org.). Diversidade Sexual na Educação. MEC/Unesco, 2009, pp. 235-263.

PEREIRA, Jane Reis Gonçalves. A aplicação de regras religiosas de acordo com a lei do Estado: um panorama do caso brasileiro. Revista da AGU, v. 41, 2014, pp. 9-42.

PIOVESAN, Flávia. Temas de Direitos Humanos. 3a Ed. São Paulo: Saraiva, 2009, p. 415.

PROCURADORIA Federal dos Direitos do Cidadão. Nota Técnica 01/2016 PFDC. 21.07.2016. Disponível em: <http://pfdc.pgr.mpf.mp.br/temas-deatuacao/educacao/saiba-mais/proposicoes-legislativas/nota-tecnica-01-2016-pfdc-mpf>. Acesso em 21.04.2017.

RIOS, Roger Raupp. "O conceito de homofobia na perspectiva dos direitos humanos e no contexto dos estudos sobre preconceito e discriminação". In: RIOS, Roger Raupp. (org.). Em Defesa dos Direitos Sexuais. Porto Alegre: Livraria do Advogado Ed., 2007, pp. 111-139.

RIOS, Roger Raupp. Direito da antidiscriminação, sexo, sexualidade e gênero: a compreensão da proibição constitucional de discriminação por motivo de sexo. SARMENTO, Daniel; IKAWA, Daniela; PIOVESAN, Flávia (coords.). Igualdade, Diferença e Direitos Humanos. Rio de Janeito: Lumen Juris, 2010, pp. 695-717.

RIOS, Roger Raupp; SANTOS, Wederson Ruffino dos. Diversidade sexual, educação e sociedade: reflexões a partir do Programa Nacional do Livro Didático In: LIONÇO, Tatiana; DINIZ, Debora. (Orgs.). Homofobia \& Educação: um desafio ao silêncio. Brasília: LetrasLivres, EdUnB, 2009, pp. 133-159.

SANTIAGO, Mylene Cristina; SANTOS, Mônica Pereira dos; MELO, Sandra Cordeiro de. "Plano Nacional de Educação (2014-2024): considerações omniléticas sobre o patrulhamento ideológico e as diferenças silenciadas". Revista Educação e Cultura Contemporânea, v. 13, n. 22, 2016, pp. 67-83.

SANTOS, Boaventura de Sousa. Reconhecer para Libertar: Os caminhos do cosmopolitismo multicultural. Rio de Janeiro: Civilização Brasileira, 2003, p. 614.

SARMENTO, Daniel. A Igualdade Étnico-Racial no Direito Constitucional Brasileiro: Discriminação 'De Facto', Teoria do Impacto Desproporcional e Ação Afirmativa. In: SARMENTO, Daniel. Livres e Iguais: Estudos de Direito Constitucional. Rio de Janeiro: Lumen Juris, 2006, pp. 139-166. 
SARMENTO, Daniel. Casamento e União Estável entre Pessoas do Mesmo Sexo: perspectivas constitucionais. SARMENTO, Daniel; IKAWA, Daniela; PIOVESAN, Flávia (coords.). Igualdade, Diferença e Direitos Humanos. Rio de Janeiro: Lumen Juris, 2010, pp. 619-659.

SARMENTO, Daniel. Ensino religioso nas escolas públicas. Jota. Publicado em 23.06.2015. Disponível em: <https://jota.info/artigos/ensino-religioso-nas-escolas-publicas23062015>. Acesso em 21.04.2017.

., Daniel. Dignidade da Pessoa Humana: conteúdo, trajetórias e metodologia. Belo Horizonte: Fórum, 2016, p. 376.

SOUZA, Elizeu Clementino de. Direitos humanos e diversidade sexual na escola: homofobia, trabalho docente e cotidiano escolar. Conjectura: filosofia e educação; v. 20, no especial, 2015, pp. 198-220.

SOUZA, Sandra Duarte. 'Não à ideologia de gênero!': a produção religiosa da violência de gênero na política brasileira. Estudos da Religião, v. 28, n. 2, 2014, pp. 188-204.

TEIXEIRA, Adla Betsaida Martins; FREITAS, Marcel de Almeida. Homofobia e misoginia na escola: enfrentamento a partir dos direitos humanos. Teoria \& Sociedade, no 21.2, 2013, pp. 292-305.

TREVISAN, João Silvério. Devassos no Paraíso: a homossexualidade no Brasil, da colônia à atualidade. 8a Ed. Rio de Janeiro: Record, 2011, p. 588.

VECCHIATTI, Paulo Roberto lotti. Fundamentos em prol da Criminalização da Homofobia e da Transfobia. Jota. Publicado em 07.07.2016. Disponível em <https://jota.info/artigos/fundamentos-em-prol-da-criminalizacao-da-homofobia-e-datransfobia-07072016>. Acesso em: 21.04.2017.

VIANNA, Adriana de Resende Barreto. Direito à Diferença: introdução. In: LIMA, Antonio Carlos de Souza (coord.). Antropologia \& Direito: temas antropológicos para estudos jurídicos. Rio de Janeiro/Brasília: Contra Capa, 2012, pp. 202-211.

VITAL, Christina; LOPES, Paulo Victor Leite. Religião e Política: uma análise da atuação dos parlamentares evangélicos sobre direitos das mulheres e de LGBTs no Brasil. Rio de Janeiro: Fundação Heinrich Böll, 2012, p. 232.

WELZER-LANG, Daniel. A Construção do Masculino: dominação das mulheres e homofobia. Estudos Feministas. Florianópolis, v. 9, n.2, 2001, pp. 460-482.

WYLLYS, Jean. Tempo Bom, Tempo Ruim: identidades, políticas e afetos. São Paulo: Paralela, 2014, p. 189.

ZAMBRANO, Elizabeth; HEILBORN, Maria Luiza. Identidade de gênero. In: LIMA, Antonio Carlos de Souza (coord.). Antropologia \& Direito: temas antropológicos para estudos jurídicos. Rio de Janeiro/Brasília: Contra Capa, 2012, pp. 413-419.

Enviado em: 08/02/2017

Aprovado em: 26/04/2017 